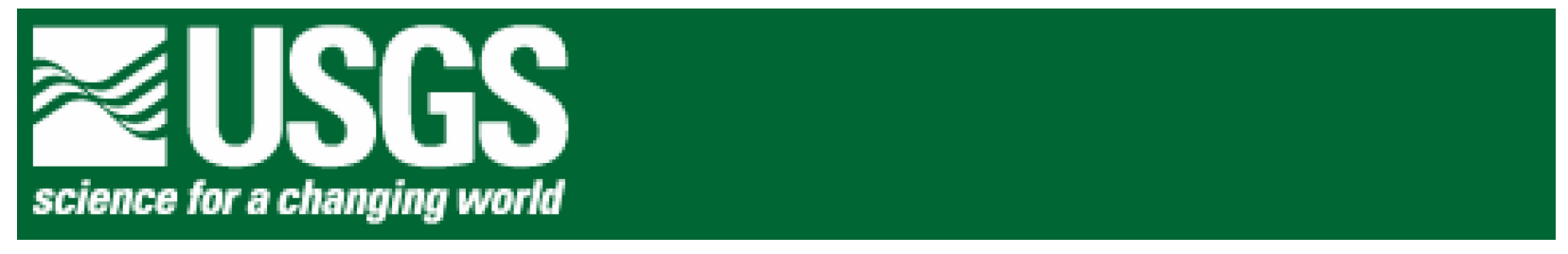

In Cooperation with the Southern Nevada Water Authority (SNWA)

\title{
Gravity Data from Dry Lake and Delamar Valleys, east-central Nevada
}

By Edward A. Mankinen, Bruce A. Chuchel, and Barry C. Moring

Open File Report 2008-1299

U.S. Department of the Interior

U.S. Geological Survey 


\section{U.S. Department of the Interior DIRK KEMPTHORNE, Secretary}

\section{U.S. Geological Survey \\ Mark D. Myers, Director}

U.S. Geological Survey, Reston, Virginia 2008

For product and ordering information:

World Wide Web: http://www.usgs.gov/pubprod

Telephone: 1-888-ASK-USGS

For more information on the USGS - the Federal source for science about the Earth,

its natural and living resources, natural hazards, and the environment:

World Wide Web: http://www.usgs.gov

Telephone: 1-888-ASK-USGS

Suggested citation:

Mankinen, Edward A., Chuchel, Bruce A., and Moring, Barry C., 2008, Gravity data from Dry Lake and Delamar Valleys, east-central Nevada: U.S. Geological Survey Open-File Report 2008-1299, 30 p. [http://pubs.usgs.gov/of/2008-1299/].

Any use of trade, product, or firm names is for descriptive purposes only and does not imply endorsement by the U.S. Government.

Although this report is in the public domain, permission must be secured from the individual copyright owners to reproduce any copyrighted material contained within this report. 


\section{Contents}

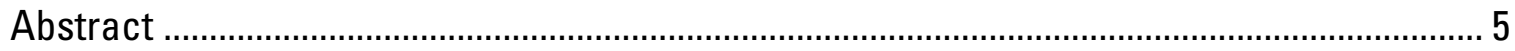

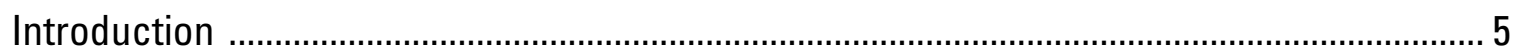

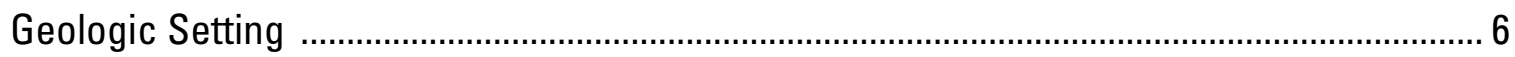

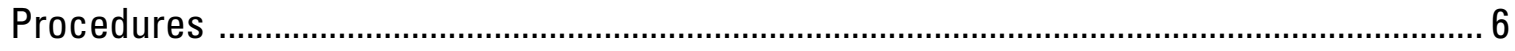

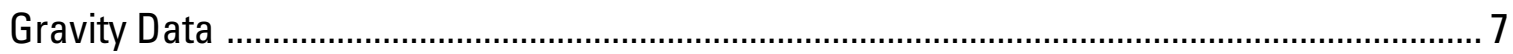

Horizontal Gradients of the Gravity Field ..................................................................... 7

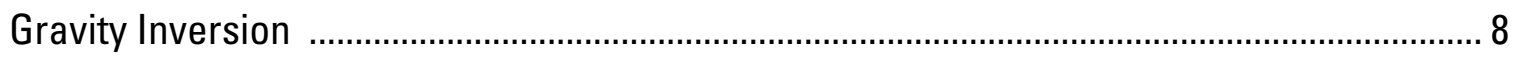

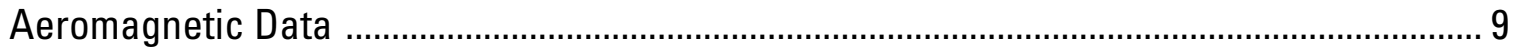

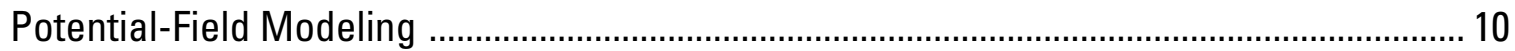

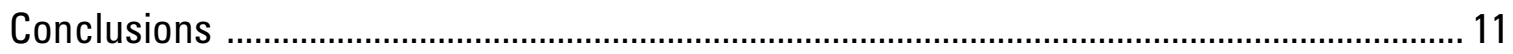

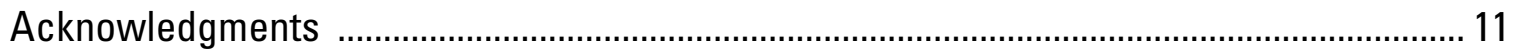

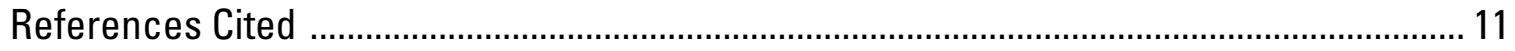

Figures

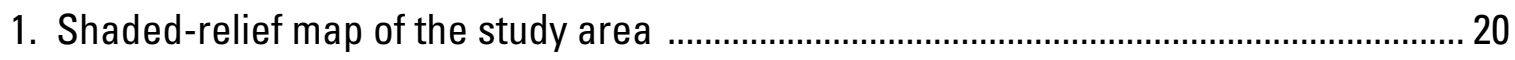

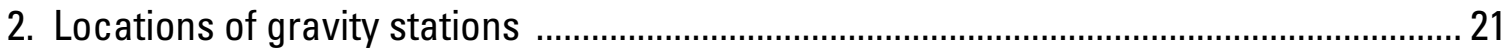

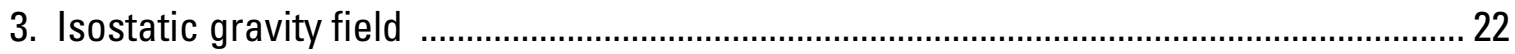

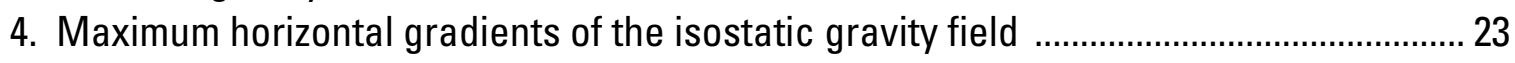

5. Shaded-relief map showing maximum horizontal gradients ............................................ 24

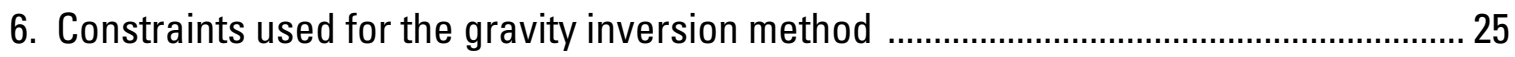

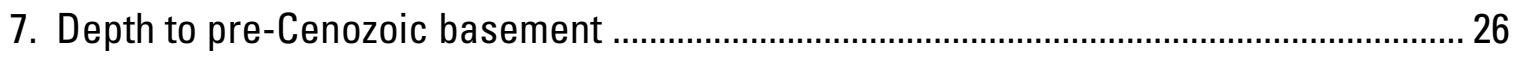

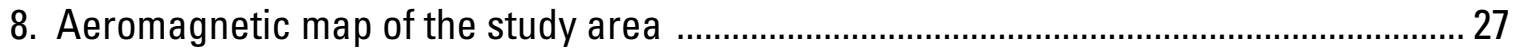

9. Transect across Dry Lake Valley ....................................................................................... 28

10. Portion of $(A)$ gravity and $(B)$ aeromagnetic grids showing

Dry Lake Valley transect .............................................................................................. 29

11. Geophysical forward model along Dry Lake Valley transect ............................................ 30

Tables

1. Principal facts of gravity stations, Dry Lake and Delamar Valleys, Nevada .................. 15

2. Cenozoic density-depth function for the Cave to Delamar Valleys study area ............... 19 


\section{Conversion Factors}

\begin{tabular}{lll}
\hline \multicolumn{1}{c}{ Multiply } & \multicolumn{1}{c}{ By } & \multicolumn{1}{c}{ To obtain } \\
\hline inch (in.) & 2.54 & centimeter $(\mathrm{cm})$ \\
\hline foot $(\mathrm{ft})$ & 0.3048 & meter $(\mathrm{m})$ \\
\hline mile $(\mathrm{mi})$ & 1.609 & kilometer $(\mathrm{km})$ \\
\hline centimeter $(\mathrm{cm})$ & 0.3937 & inch $(\mathrm{in})$. \\
\hline meter $(\mathrm{m})$ & 3.281 & foot $(\mathrm{ft})$ \\
\hline kilometer $(\mathrm{km})$ & 0.6214 & mile $(\mathrm{mi})$ \\
\hline $\begin{array}{l}\text { kilogram per cubic meter } \\
\left(\mathrm{kg} / \mathrm{m}^{3}\right)\end{array}$ & 0.06242 & pound per cubic foot $\left(\mathrm{lb} / \mathrm{ft}^{3}\right)$ \\
\hline
\end{tabular}

Vertical coordinate information is referenced to the North American Vertical Datum of 1929 (NAVD29). Horizontal coordinate information is referenced to the North American Datum of 1927 (NAD27). 


\title{
Gravity Data from Dry Lake and Delamar Valleys, East- Central Nevada
}

\author{
By Edward A. Mankinen, Bruce A. Chuchel, and Barry C. Moring'
}

\begin{abstract}
Cenozoic basins in eastern Nevada and western Utah constitute major ground-water recharge areas in the eastern part of the Great Basin, and our continuing studies are intended to characterize the geologic framework of the region. Prior to these investigations, regional gravity coverage was variable over the region, adequate in some areas and very sparse in others. The current study in Nevada provides additional high-resolution gravity along transects in Dry Lake and Delamar Valleys to supplement data we established previously in Cave and Muleshoe Valleys. We combine all previously available gravity data and calculate an up-to-date isostatic residual gravity map of the study area. Major density contrasts are identified, indicating zones where Cenozoic tectonic activity could have been accommodated. A gravity inversion method is used to calculate depths to pre-Cenozoic basement rock and to estimate maximum alluvial/volcanic fill in the valleys. Average depths of basin fill in the deeper parts of Cave, Muleshoe, Dry Lake, and Delamar Valleys are approximately 4 km, 2 km, $5 \mathrm{~km}$, and $3 \mathrm{~km}$, respectively.
\end{abstract}

\section{Introduction}

The arid southwestern United States, historically, has been sparsely populated, but the construction of dams, aqueducts, and pumping of ground water allowed the relatively recent growth of major population centers throughout the Great Basin, with Nevada being one of the fastest-growing states in the Union. Increased demands on existing supplies, specifically the Colorado River system, have focused attention on finding new, alternative sources of water, such as in the Great Basin regional aquifer system, a vast spring and ground-water system described by Harrill and Prudic (1998). A major aquifer in the eastern part of the Great Basin occurs in a regionally extensive, thick stratigraphic sequence of Paleozoic carbonate rocks (Welch and others, 2007), with a second important system occurring in the Cenozoic basin-fill deposits throughout the entire Great Basin. The current study is a continuation of a cooperative effort between the U.S. Geological Survey (USGS) and the Southern Nevada Water Authority (SNWA) to characterize the geophysical framework of several of these Cenozoic basins in eastern Nevada and western Utah. Gravity and magnetic data are described by Scheirer (2005) and Mankinen and others (2006, 2007, and this report), and data from concurrent audiomagnetotelluric (AMT) studies are described separately by McPhee and others (2006, 2007, 2008). This study covers an area in east-central Nevada from Cave Valley southward through Delamar Valley (fig. 1; herein referred to as the study area). Results of these studies are significantly increasing our understanding of the formation and subsurface shapes of the basins in this region and are providing insights into the structures that may impede or enhance groundwater flow.

\footnotetext{
${ }^{1}$ U.S. Geological Survey, 345 Middlefield Road, Menlo Park, CA 94025.
} 


\section{Geologic Setting}

Geologic summaries of Lincoln County, Nev., can be found in Tschanz and Pampeyan (1970) and Dixon and others (2007). Additional geologic information can be found in Stewart (1980), Ekren and others (1977), and Stewart and Carlson (1978). The oldest rocks exposed in the study area are Late Proterozoic to Cambrian metamorphic rocks in the Delamar Mountains to the south and east of Delamar Valley. Where not greatly faulted and fractured, metamorphic rock forms an effective barrier to ground-water flow and may form the base of the carbonaterock aquifer in areas where circulation extends throughout the entire stratigraphic thickness (Plume, 1996; Harrill and Prudic, 1998). These metamorphic rocks are overlain by Paleozoic carbonate and shale. Paleozoic strata form the bedrock in the other ranges of the study area. The North Pahroc and South Pahroc Ranges and the Delamar Mountains are capped with highly faulted Tertiary volcanic rocks from the Caliente caldera complex (Rowley and others, 1995). Although impermeable in hand sample, these densely-welded tuffs are easily fractured, allowing water circulation, and can form locally significant aquifers.

Plutons likely exist beneath all calderas and many have been inferred throughout the region from interpretations of geophysical anomalies (Grauch and others, 1988; Ponce, 1990). Although plutons of the region range from Jurassic to Tertiary in age, all are grouped with the basement rocks because their density is similar to most of the pre-Cenozoic rocks, differing greatly from those of later volcanic and other basin-fill rocks. Intrusive igneous rocks typically are barriers to ground-water flow (Plume, 1996), except in areas where extensively fractured.

Major extensional faulting began throughout the Basin and Range Province at about 17 Ma (McKee, 1971; Christiansen and McKee, 1978; Stewart, 1978) and formed the horst-graben terrain that is well expressed in the study area (fig. 1). Most of the valleys are drained internally and contain playas. Alluvial fill within the basins may range from a few hundred meters to several kilometers thick. Basin fill in the study area consists of alluvial material derived from the erosion of adjacent mountain ranges and is characterized by semi-consolidated to unconsolidated sand, gravel, silt, clay, and local evaporites with some interbedded volcanic units in many areas. The sand and gravel deposits form a major, shallow aquifer in the region where they are not clogged by clay or zeolitic intergranular materials. These aquifers are in close proximity to the surface and easily reached by wells and, thus, are commonly exploited. Some of these basin-fill aquifers are hydraulically isolated from similar aquifers in adjacent valleys, while other aquifers are hydraulically connected by flow through the underlying carbonate aquifer (Plume, 1996).

\section{Procedures}

Gravity data were obtained by using a LaCoste and Romberg meter (G614), and observed gravity values were referenced to a local gravity base station in Caliente (CALTRN) established by Scheirer (2005). This station was tied to the International Gravity Standardization Net 1971 (ISGN 71) gravity datum (Morelli, 1974) at the Ely, Nev. airport (ELYA) via double-loop surveying. Base station CALTRN, at $37^{\circ} 36.732^{\prime} \mathrm{N},-114^{\circ} 30.831^{\prime} \mathrm{W}$, has an observed gravity value of $979,515.51 \mathrm{mGal}$. Locations of gravity stations were determined by using a differential Global Positioning System (DGPS) receiver, with corrections provided by Continually Operated Reference Station (CORS) satellites. Locations after post-acquisition processing are accurate to within 1 meter, both horizontally and vertically. 


\section{Gravity Data}

Scheirer (2005), in cooperation with SNWA, established 468 new gravity stations in the study area to improve the regional coverage in the region (fig. 2). Mankinen and others (2007) later provided additional high-resolution gravity, primarily in Muleshoe Valley. We added 185 additional stations (table 1 and fig. 2) along selected traverses in the study area to supplement our high-resolution gravity data and, thus, better define basin geometry and structural boundaries. Observed gravity at each station was adjusted by assuming a time-dependent linear drift between readings of a base station at the start and finish of each daily survey. This adjustment compensates for drift in the instrument's spring. Observed gravity values are considered accurate to about $0.05 \mathrm{mGal}$ based on repeat measurements over several mountain calibration loops (Barnes and others, 1969; Ponce and Oliver, 1981).

Gravity data were reduced using standard gravity corrections (Blakely, 1995) and a reduction density of $2,670 \mathrm{~kg} / \mathrm{m}^{3}$. Field terrain corrections (zones A and B of Hayford and Bowie, 1912) were carried out to $68 \mathrm{~m}$ by using templates and charts (Plouff, 2000). Inner-zone terrain corrections for zones C and D (Hayford and Bowie, 1912), which are necessary to account for variations in topography near a gravity station, were obtained to a radial distance of 2 $\mathrm{km}$ by using digitized topography in a digital elevation model (DEM) (D. Plouff, USGS, written commun., 2006). Outer terrain corrections, from $2 \mathrm{~km}$ to $167 \mathrm{~km}$, also are calculated by using digitized topography and a procedure by Plouff (1977). The resulting gravity anomaly is termed the complete Bouguer anomaly. A regional isostatic field was calculated by using an AiryHeiskanen model (Heiskanen and Vening Meinesz, 1958) for local compensation of topographic loads (Jachens and Roberts, 1981; Simpson and others, 1986). The Airy-Heiskanen model assumes a nominal crustal thickness of $25 \mathrm{~km}$, a crustal density of $2,670 \mathrm{~kg} / \mathrm{m}^{3}$, and a $400 \mathrm{~kg} / \mathrm{m}^{3}$ density contrast between the crust and mantle. This regional isostatic field was subtracted from the complete Bouguer anomaly, thus removing long-wavelength variations in the gravity field that are inversely related to topography. The resulting isostatic residual gravity anomaly, therefore, is a reflection of local density distributions within middle to upper crustal levels.

Gravity data obtained during the current study, and their associated parameters, are shown in table 1 and are available online for download as an Excel spreadsheet. Other gravity data available for the study area are from Scheirer (2005) and an earlier compilation by Ponce (1997). Because gravity data for the study area were made by many different observers at different times, we examined the composite data set to remove duplicate and inconsistent entries. To test for possible errors, we first compared reported station elevations with elevations interpolated from 10- and 30-meter DEMs by using a procedure by D. Plouff (USGS, written commun., 2005). Large elevation differences indicate possible errors in station location or elevation, and each station identified was examined individually to confirm the discrepancy. Some of these errors occurred because of imprecise locations (for example, lack of significant digits in published reports) and were corrected with a high degree of confidence. If the source of the discrepancy could not be determined and corrected, the station was omitted from the data set. Observations from the revised data set were then gridded at a spacing of $0.5 \mathrm{~km}$ by using the minimum curvature algorithm of Webring (1981), and the resulting isostatic residual gravity field (fig. 3) is considered reliable for subsequent analyses.

\section{Horizontal Gradients of the Gravity Field}

Because our studies are intended to help characterize the geologic structures and framework controlling regional ground-water flow, we begin by calculating horizontal gradients for the gravity field shown in figure 3 (Cordell, 1979; Blakely, 1995). When calculated for two- 
dimensional data grids, these horizontal gradients will place narrow ridges over significant changes in gravity. The method of Blakely and Simpson (1986) was then used to calculate maximum values of these gradients, the locations of which tend to overlie the edges of causative bodies with abrupt, near-vertical contacts. All maxima ("maxspots") in the horizontal gradients are indicated by the small crosses in figure 4 . The gravity anomalies in figure 3 were next analytically upward-continued by 1 and $2 \mathrm{~km}$ (Hildenbrand, 1983) to de-emphasize surface and near-surface features and enhance the contribution of deeper sources. Again, horizontal gradients were calculated, and the maxima in the 2-km, upward-continued data are indicated by the colored dots in figure 4 . Because Cenozoic tectonic activity may be accommodated along significant density contrasts, identification of them can help locate subsurface faults.

We emphasize that the locations of maxima in the horizontal gradients tend to overlie the edges of causative bodies with abrupt, near-vertical contacts. For non-vertical contacts between geologic units of contrasting densities, maximum values of the horizontal gradients will be displaced down-dip and away from the edges of the body. Possible examples of both situations are indicated when the shallow and deeper maxima from figure 4 are superimposed on the shaded relief map in figure 5. Note areas where the lines of maxspots are up against the range fronts and are indicative of nearly vertical basin-bounding faults. In other cases, the lines of maxspots are displaced basin-ward of the mapped range-front faults and may be indicative of listric faulting. Alternatively, Scheirer (2005) has suggested that the maxspots within Dry Lake Valley may represent significant faults below the alluvium that formed a narrow, slot-like graben along the axis of the valley. Some of these possibilities will be revisited in a later section.

A long, quasi-continuous line of maxspots parallel the eastern margins of both Dry Lake and Delamar Valleys (fig. 5). The western margin of Delamar Valley is displaced considerably westward of the same margin of Dry Lake Valley. The displacement appears to have been accommodated along an E-W line of maxspots perhaps representing one of the enigmatic transverse zones (Rowley, 1998; Rowley and Dixon, 2001) sometimes noted in the Great Basin. These transverse zones typically are reflected by east-striking faults and folds, alignments of plutons and volcanic vents, and various alignments of local features (for example, springs, altered rock, mineral deposits). A belt of faulted rocks with low relief occurs in the area between Dry Lake and Delamar Valleys and is termed the "Timpahute transverse zone" (Rowley, 1998; Dixon and others, 2007).

\section{Gravity Inversion}

To first order, the isostatic residual gravity field (fig. 3) reflects the pronounced contrast between dense $\left(\sim 2,670 \mathrm{~kg} / \mathrm{m}^{3}\right)$ pre-Cenozoic basement rocks and the significantly less dense (generally $<2,500 \mathrm{~kg} / \mathrm{m}^{3}$ ) overlying volcanic and sedimentary basin-fill. Because of this relationship, the gravity inversion method of Jachens and Moring (1990) can be used to separate the isostatic residual anomaly into pre-Cenozoic "basement" and Cenozoic "basin" fields, thus allowing an estimate of thickness of Cenozoic alluvial fill within the area. The accuracy of thickness estimates derived by the gravity-inversion technique depends on the assumed densitydepth relation of the Cenozoic rocks and on the initial density assigned to the basement rocks.

Density of basement rocks is generally assumed to be $2,670 \mathrm{~kg} / \mathrm{m}^{3}$, and this value is considered appropriate in this study area where major exposures consist of late Precambrian through late Paleozoic marine carbonate and quartzose sedimentary rocks. Subvolcanic Cenozoic intrusions are included here as part of the basement because their physical properties are similar to most of the older rocks, and differ greatly from those of the eruptive and basin-fill 
sedimentary sequences. The density of basin-fill deposits generally increases with the degree of compaction and consolidation and, thus, usually correlates with depth of burial, as well as with other factors, such as increasing water content. The density-versus-depth relationship we use (table 2) is the same used by Jachens and Moring (1990) and Saltus and Jachens (1995) to separate the isostatic residual anomaly into basement and basin fields, and is similar to those relationships shown to be widely applicable to other volcanic basin-fill deposits throughout Nevada (Blakely and others, 1998, 2000; Mankinen and others, 2003).

In the inversion process, the density of basement is allowed to vary horizontally but the density of basin-filling deposits is fixed by using the density-depth distribution (table 2). In this iterative approach, a first approximation of the basement gravity field is derived from those gravity measurements made on exposed pre-Cenozoic rocks (figure 6), and gravity values approximated by correcting the isostatic gravity anomaly at sites where depth to basement is known from deep boreholes (Garside and others, 1988; Hess, 2004). At locations where wells did not penetrate the full thickness of basin fill, the maximum depths reached were used as minimum constraints in the iterative process. Information on oil and gas wells for Nevada and Utah is available at http://www.nbmg.unr.edu/lists/oil/oil.htm and http://ogm.utah.gov/oilgas/, respectively (last accessed September 19, 2008).

The basement gravity field ignores the gravity effects of nearby basins and is subtracted from the observed gravity, which provides the first approximation of the basin gravity field. Again using the selected density-depth relation, the thickness of the basin-filling deposits is calculated. The gravitational effect of this first approximation of the basin-filling layer is computed at each known basement station. This effect is, in turn, subtracted from the first approximation of the basement gravity field, and the process is repeated until successive iterations produce no substantial changes in the basement gravity field. Gravity was inverted over the area described in Mankinen and others (2007) by using the drill-hole constraints described therein. Results of the inversion were gridded at a spacing of $2.0 \mathrm{~km}$ by using the minimum curvature algorithm of Webring (1981), and the map shown in figure 7 was extracted from the larger grid.

\section{Aeromagnetic Data}

Aeromagnetic surveys of the Great Basin and Nevada were presented by Zietz and others (1978), Mabey and others (1978), Hildenbrand and others (1983), and Hildenbrand and Kucks (1988). Flight-line spacing of aeromagnetic surveys over most of Nevada ranged between 5 and $1.6 \mathrm{~km}(1.6 \mathrm{~km}$ within the study area), and the data shown in figure 8 were extracted from the aeromagnetic map of Nevada (see Kucks and others, 2006). Many anomalies are seen, due to the presence of strongly magnetic volcanic rocks from the Indian Peak and Caliente caldera complexes (Best, Christiansen, and Blank, 1989; Best and others, 1989). Some of the strong magnetic highs are associated with mapped outcrops of volcanic rock, and the continuation of these anomalies indicate that the rocks also are present and perhaps more extensive in the subsurface. Magnetic lows may indicate reversed polarity volcanic rocks and, in some cases, weakly magnetic plutonic rocks, such as the Tungstonia Granite of Best and others (1974) that forms the core of the Kern Mountains. This atypical composite pluton is a deeply weathered, two-mica granite containing phenocrystic muscovite, abundant aplite dikes, and aplitic borders, all probably contributing to its weak magnetic signature. Similar weakly magnetic plutonic rocks may be concealed throughout the region as first discussed by Blakely (1988), and these would be difficult to detect. 


\section{Potential-Field Modeling}

We now have high resolution gravity observations along several transects throughout the study area (figs. 1 and 2) that can be combined with available aeromagnetic data to construct initial geologic models of the subsurface by using a commercially available $2 \frac{1}{2} 2_{\text {-dimensional }}$ modeling program based on Webring (1985). The program requires an initial estimate of model parameters and varies them to reduce the weighted root-mean-square error between observed and calculated gravity and magnetic values along the transect. We assume a density of $2,670 \mathrm{~kg} / \mathrm{m}^{3}$ for basement rocks and vary the density of basin-fill according to the relationships given in table 2. When the magnetization direction of rocks spanning an appreciable length of time (on the order of $10^{4}$ years) are averaged, their mean direction will correspond to one produced by a geocentric axial-dipole field (here we use inclination $= \pm 60^{\circ}$, declination $=0^{\circ}$ or $180^{\circ}$ ). Total magnetizations can be more difficult to characterize because intensity of magnetization can vary with position within a volcanic cooling unit, as well as with rock composition, magnetic grain size, and concentration of magnetic minerals. For volcanic rocks typical of the study area, magnetizations commonly range from 0.1 to $1 \mathrm{~A} / \mathrm{m}$, although it is not unusual for specific units to have magnetization intensities well outside this range. For our models, we begin by assuming a magnetization of $0.8 \mathrm{~A} / \mathrm{m}$. Because of these strong remanent magnetizations, we also assume that an induced component can be ignored. Such models can be further constrained by drill-hole information and geologic cross-sections, where available, and by results from a gravity inversion. We emphasize, however, that any solutions obtained are not unique because an infinite number of geometric models will have an associated field that closely matches the measured field.

Here we provide an interpretative geophysical model along a transect (colored line) across the central part of Dry Lake Valley (fig. 9). Gravity and magnetic data were extracted along the two segments of this transect, separated by the bend in section. These segments were then combined to yield quasi-continuous profiles as shown in figures 11A and 11B. Although the differing trends of the two segments of the transect were not accounted for in our preliminary model (fig. 11C), the change in trend is too small to have seriously affected our interpretation. Refined models, however, will have to factor in this change in direction. Also shown in figure 11 are the locations of maxspots described earlier. All maxima in the gravity field are indicated by the small crosses, maxima in the 1-km upward-continued data by the red dots, and maxima in the 2-km upward-continued data by the white dots. Although there is a prominent line of maxspots trending along the axis of the valley, note that there is also an alignment of maxspots (representing shallower contrasts) trending along the foot of the North Pahroc Range on the western margin of the valley. Gravity and magnetic data in the vicinity of the transect are shown in figure 10 .

Results of the interpretive geophysical model are shown in figure 11. Volcanic rocks are exposed at the surface along the western part of the transect, and the strong magnetic anomaly over the central valley also indicates their presence in the subsurface. The magnetic data were fit by assigning a reversed magnetic polarity for the rocks to the west (shown in red shading) and a normal magnetic polarity (blue shading) for the volcanic rocks buried beneath the valley fill. This particular model seems to require another block of volcanic rock (with reversed magnetic polarity) overlying basement at the eastern end of the transect, but these apparently occur at relatively shallow depths. Alluvial fill becomes denser with depth of burial as depicted by the shading in the figure. Note the locations of the maxspots from figure 8 with respect to the inferred faults on the model. 


\section{Conclusions}

Gravity data collected during the course of our cooperative studies have allowed a much improved definition of basins in the study area. Mankinen and others (2006) compared their depth-to-basement calculations for the Spring and Snake Valleys area with a previously published map (Saltus and Jachens, 1995), illustrating the importance of an improved data distribution and incorporation of drill-hole data not available for the earlier interpretation. Our latest depth-to-basement calculations (fig. 7) for the study area (fig. 1) are further refinements to those of Scheirer (2005) and Mankinen and others (2006, 2007). Average depths of basin fill in the deeper parts of Cave, Muleshoe, Dry Lake, and Delamar Valleys are approximately $4 \mathrm{~km}, 2$ $\mathrm{km}, 5 \mathrm{~km}$, and $3 \mathrm{~km}$, respectively. In limited areas, depths may approach $\sim 5 \mathrm{~km}$ in Cave Valley and $\sim 6.5 \mathrm{~km}$ in Dry Lake Valley. Identification of major density contrasts (figs. 4 and 5) will help in locating potential subsurface faults and geologic contacts that may control regional ground-water flow. Many of these contrasts clearly reflect basin-bounding faults, indicating typical Basin and Range horst-graben structures.

\section{Acknowledgements}

This study was performed with the cooperation of the Southern Nevada Water Authority (SNWA) whose support is greatly appreciated. Reviews by J.M.G. Glen and D.K. McPhee, and informal comments by G.L. Dixon, helped to clarify and improve the manuscript. Discussions with G.L. Dixon during the course of this study proved very helpful.

\section{References Cited}

Barnes, D.F., Oliver, H.W., and Robbins, S.L., 1969, Standardization of gravimeter calibrations in the Geological Survey: Eos, Transactions of the American Geophysical Union, v. 50, p. 526-527.

Best, M.G., Christiansen, E.H., and Blank, H.R., Jr., 1989, Oligocene calc-alkaline rocks of the Indian Peak volcanic field, Nevada and Utah: Geological Society of America Bulletin, v. 101, p. 1076-1090.

Best, M.G., Armstrong, R.L., Graustein, W.C., Embree, G.F., and Ahlborn, R.C., 1974, Mica granites of the Kern Mountains pluton, eastern White Pine county, Nevada: Remobilized basement of the Cordilleran miogeosyncline?: Geological Society of America Bulletin, v. 85 , p. $1277-1286$.

Best, M.G., Christiansen, E.H., Deino, A.L., Grommé, C.S., McKee, E.H., and Noble, D.C., 1989, Eocene through Miocene volcanism in the Great Basin of the western United States, in Chapen, C.E., and Zedik, V., eds., Field excursions to volcanic terranes in the western United States, v. II: Cascades and Intermountain west: New Mexico Bureau of Mines and Mineral Resources Memoir 47, p. 91-133.

Blakely, R.J., 1988, Curie temperature isotherm analysis and tectonic implications of aeromagnetic data from Nevada: Journal of Geophysical Research, v. 93, p. 11,81711,832 .

Blakely, R.J., 1995, Potential theory in gravity and magnetic applications: Cambridge, Cambridge University Press, $441 \mathrm{p}$.

Blakely, R.J., and Simpson, R.W. 1986, Approximating edges of source bodies from magnetic or gravity anomalies: Geophysics, v. 51, p. 1494-1498.

Blakely, R.J., Langenheim, V.E., Ponce, D.A., and Dixon, G.L., 2000, Aeromagnetic survey of the Amargosa Desert, Nevada and California: A tool for understanding near-surface geology and hydrology: U.S. Geological Survey Open-File Report 00-188, 35 p. 
Blakely, R.J., Morin, R.L., McKee, E.H., Schmidt, K.M., Langenheim, V.E., and Dixon, G.L., 1998, Three-dimensional model of Paleozoic basement beneath Amargosa Desert and Pahrump Valley, California and Nevada: Implications for tectonic evolution and waterresources: U.S. Geological Survey Open-File Report 98-496, 27 p.

Christiansen, R.L., and McKee, E.H., 1978, Late Cenozoic volcanic and tectonic evolution of the Great Basin and Columbia Intermontane regions, in Smith, R.B., and Eaton, G.P., eds., Cenozoic tectonics and regional geophysics of the Western Cordillera: Geological Society of America Memoir 152, p. 283-311.

Cordell, L., 1979, Gravimetric expression of graben faulting in Santa Fe County and the Española Basin, in Ingersoll, R.V., ed., Guidebook to Santa Fe County, 30th Field Conference: New Mexico Geological Society, p. 59-64.

Dixon, G.L., Rowley, P.D., Burns, A.G., Watrus, J.M., and Ekren, E.B., 2007, Geology of White Pine County and Lincoln Counties and adjacent areas, Nevada and Utah, in The geologic framework of regional groundwater flow systems: Southern Nevada Water Authority, Document No. HAM-ED-0001, 129 p.

Ekren, E.B., Orkild, P.P., Sargent, K.A., and Dixon, G.L., 1977, Geologic map of Tertiary rocks, Lincoln County, Nevada: U.S. Geological Survey Miscellaneous Investigations Series Map I-1041, scale 1:250,000.

Garside, L.J., Hess, R.H., Fleming, K.L., and Weimer, B.S., 1988, Oil and gas developments in Nevada: Nevada Bureau of Mines and Geology Bulletin 104 (on-line database, updated June, 2004).

Grauch, V.J.S., Blakely, R.J., Blank, H.R., Oliver, H.W., Plouff, D., and Ponce, D.A., 1988, Geophysical delineation of granitic plutons in Nevada: U.S. Geological Survey OpenFile Report 88-11, scale 1:1,000,000.

Harrill, J.R., and Prudic, D.E., 1998, Aquifer systems in the Great Basin region of Nevada, Utah, and adjacent states-Summary report: U.S. Geological Survey Professional Paper 1409A, $66 \mathrm{p}$.

Hayford, J.F., and Bowie, William, 1912, The effect of topography and isostatic compensation upon the intensity of gravity: U.S Coast and Geodetic Survey Special Publication 10, $132 \mathrm{p}$.

Heiskanen, W.A., and Vening Meinesz, F.A., 1958, The Earth and its Gravity Field: New York, McGraw-Hill, 470 p.

Hess, R.H., 2004, Nevada oil and gas well database (NVOILWEL): Nevada Bureau of Mines and Geology Open-File Report 04-1, 288 p.

Hildenbrand, T.G., 1983, FFTFIL: A filtering program based on two-dimensional Fourier analysis: U.S. Geological Survey Open-File Report 83-237, 61 p.

Hildenbrand, T.G., and Kucks, R.P., 1988, Total intensity magnetic anomaly map of Nevada: Nevada Bureau of Mines and Geology Map 93A, scale 1:750,000.

Hildenbrand, T.G., Kucks, R.P., and Sweeney, R.E., 1983, Digital colored magnetic-anomaly map of the Basin and Range Province: U.S. Geological Survey Open-File Report 83-189, $11 \mathrm{p}$.

Jachens, R.C., and Moring, B.C., 1990, Maps of the thickness of Cenozoic deposits and the isostatic residual gravity over basement for Nevada: U.S. Geological Survey Open-File Report 90-404, 15 p.

Jachens, R.C., and Roberts, C.W., 1981, Documentation of program, ISOCOMP, for computing isostatic residual gravity: U.S. Geological Survey Open-File Report 81-574, 26 p.

Kucks, R.P., Hill, P.L., and Ponce, D.A., 2006, Nevada magnetic and gravity maps and data: A website for the distribution of data: U.S. Geological Survey Digital Data Series DS-234. 
Mabey, D.R., Zietz, I., Eaton, G.P., and Kleinkopf, M.D., 1978, Regional magnetic patterns in part of the Cordillera in the western United States, in Smith, R.B., and Eaton, G.P., eds., Cenozoic Tectonics and Regional Geophysics of the Western Cordillera: Geological Society of America Memoir 152, p. 93-105.

Mankinen, E.A., Hildenbrand, T.G., Fridrich, C.J., McKee, E.H., and Schenkel, C.J., 2003, Geophysical setting of the Pahute Mesa-Oasis Valley region, southern Nevada: Nevada Bureau Mines and Geology Report 50, CD-ROM, 45 p.

Mankinen, E.A., Roberts, C.W., McKee, E.H., Chuchel, B.A., and Morin, R.L., 2007, Geophysical data from Spring Valley to Delamar Valley, east-central Nevada: U.S. Geological Survey Open-File Report 2007-1190, 43 p.

Mankinen, E.A., Roberts, C.W., McKee, E.H., Chuchel, B.A., and Moring, B.C., 2006, Geophysical data from the Spring and Snake Valleys area, Nevada and Utah: U.S. Geological Survey Open-File Report 2006-1160, 42 p.

McKee, E.H., 1971, Tertiary igneous chronology of the Great Basin of western United StatesImplications for tectonic models: Geological Society of America Bulletin, v. 82, p. 3497-3502.

McPhee, D.K., Chuchel, B.A., and Pellerin, L., 2006, Audiomagnetotelluric data from Spring, Cave, and Coyote Spring Valleys, Nevada: U.S. Geological Survey Open-File Report 2006-1164, $41 \mathrm{p}$.

McPhee, D.K., Chuchel, B.A., and Pellerin, L., 2007, Audiomagnetotelluric data and 2D models from Spring, Snake, and Three Lakes Valleys, Nevada: U.S. Geological Survey OpenFile Report 2007-1181, 94 p.

McPhee, D.K., Chuchel, B.A., and Pellerin, L., (in press), Audiomagnetotelluric data and preliminary two-dimensional models from Spring, Dry Lake, and Delamar Valleys, Nevada: U.S. Geological Survey Open-File Report 2008-1301.

Morelli, C., ed., 1974, The International Gravity Standardization Net 1971: International Association of Geodesy Special Publication 4, 194 p.

Plouff, Donald, 1977, Preliminary documentation for a FORTRAN program to compute gravity terrain corrections based on topography digitized on a geographic grid: U.S. Geological Survey Open-File Report 77-535, 45 p.

Plouff, Donald, 2000, Field estimates of gravity terrain corrections and Y2K-compatible method to convert from gravity readings with multiple base stations to tide- and long-term driftcorrected observations: U.S. Geological Survey Open-File Report 00-140, 37 p.

Plume, R.W., 1996, Hydrogeologic framework of the Great Basin region of Nevada, Utah and adjacent states: U.S. Geological Survey Professional Paper 1409-B, 64 p.

Ponce, D.A., 1990, Gravity and magnetic anomalies in the Ely quadrangle, Nevada, and anomalies related to granitic plutons, in Geology and ore deposits of the Great Basin: Reno, Geological Society of Nevada, p.103-106.

Ponce, D.A., 1997, Gravity data of Nevada: U.S. Geological Survey Digital Data Series DDS-42, CD-ROM, 27 p.

Ponce, D.A., and Oliver, H.W., 1981, Charleston Peak gravity calibration loop, Nevada: U.S. Geological Survey Open-File Report 81-985, 20 p.

Rowley, P.D., 1998, Cenozoic transverse zones and igneous belts in the Great Basin, western United States - their tectonic and economic implications, in Faulds, J.E., and Stewart, J.H., eds., Accommodation zones and transfer zones-The regional segmentation of the Basin and Range Province: Geological Society of America Special Paper 323, p. 195228. 
Rowley, P.D., and Dixon, G.L., 2001, The Cenozoic evolution of the Great Basin area, U.S.A. New interpretations based on regional geologic mapping, in Erskine, M.C., Faulds, J.E., Bartley, J.M., and Rowley, P.D., eds., The geologic transition, High Plateaus to Great Basin A symposium and field guide (The Mackin Volume): Utah Geological Association and Pacific Section of the American Association of Petroleum Geologists, Utah Geological Association Publication 30, p. 169-188.

Rowley, P.D., Nealey, L.D., Unruh, D.M., Snee, L.W., Mehnert, H.H., Anderson, R.E., and Grommé, C.S., 1995, Stratigraphy of Miocene ash-flow tuffs in and near the Caliente caldera complex, southeastern Nevada and southwestern Utah, in Scott, R.B., and Swadley, W.C., eds., Geologic studies in the Basin and Range Colorado Plateau transition in southeastern Nevada, southwestern Utah, and northwestern Arizona, 1992: U.S. Geological Survey Bulletin 2056, p. 43-88.

Saltus, R.W., and Jachens, R.C., 1995, Gravity and basin-depth maps of the Basin and Range Province, western United States: U.S. Geological Survey Geophysical Investigations Map GP-1012, scale 1:2,500,000.

Scheirer, D.S., 2005, Gravity studies of Cave, Dry Lake, and Delamar Valleys, east-central Nevada: U.S. Geological Survey Open-File Report 2005-1339, 27 p.

Simpson, R.W., Jachens, R.C., Blakely, R.J., and Saltus, R.W., 1986, A new isostatic residual gravity map of the conterminous United States, with a discussion of the significance of the isostatic residual anomalies: Journal of Geophysical Research, v. 91, p. 8348-8372.

Stewart, J.H., 1978, Basin-range structure in western North America: A review, in Smith, R.B., and Eaton, G.P., eds., Cenozoic tectonics and regional geophysics of the Western Cordillera: Geological Society of America Memoir 152, p. 1-31.

Stewart, J.H., 1980, Geology of Nevada: Nevada Bureau of Mines and Geology Special Publication 4, 126 p.

Stewart, J.H., and Carlson, J.E., 1978, Geologic Map of Nevada: U.S. Geological Survey, scale 1:500,000.

Tschanz, C.M., and Pampeyan, E.H., 1970, Geology and mineral deposits of Lincoln County, Nevada: Nevada Bureau of Mines and Geology Bulletin 73, 188 p.

Webring, M., 1981, MINC,-A gridding program based on minimum curvature: U.S. Geological Survey Open-File Report 81-1224, 43 p.

Webring, M., 1985, SAKI-FORTRAN program for generalized linear inversion of gravity and magnetic profiles: U.S. Geological Survey Open-File Report 85-122, 29 p.

Welch, A.H., Bright, D.J., and Knochenmus, L.A., eds., 2007, Water resources of the Basin and Range carbonate-rock aquifer system, White Pine County, Nevada, and adjacent areas in Nevada and Utah: U.S. Geological Survey Scientific Investigations Report 2007-5261, $96 \mathrm{p}$.

Zietz, I., Gilbert, F.P., and Kirby, J.R., Jr., 1978, Aeromagnetic map of Nevada: Color coded intensities: U.S. Geological Survey Geophysical Investigations Map GP-922, scale $1: 1,000,000$. 
Table 1. Principal facts for new gravity stations, Dry Lake \& Delamar Valleys, Nevada.

[Station coordinates, NAD27; elevations, NAVD29; Bouguer anomaly calculated using a reduction density of $2,670 \mathrm{~kg} / \mathrm{m}^{3}$; terrain corrections calculated out to $166.7 \mathrm{~km}$ ]

\begin{tabular}{|c|c|c|c|c|c|c|c|c|}
\hline $\begin{array}{l}\text { Station } \\
\text { Name }\end{array}$ & $\begin{array}{l}\text { Longitude } \\
{ }^{\circ} \mathbf{W}\end{array}$ & $\begin{array}{l}\text { Latitude } \\
{ }^{\circ} \mathrm{N}\end{array}$ & $\begin{array}{c}\text { Elevation } \\
\text { (meters) }\end{array}$ & $\begin{array}{l}\text { Observed } \\
\text { gravity } \\
\text { (mGal) }\end{array}$ & $\begin{array}{c}\text { Free air } \\
\text { anomaly } \\
\text { (mGal) }\end{array}$ & $\begin{array}{c}\text { Total } \\
\text { terrain } \\
\text { Correction } \\
\text { (mGal) }\end{array}$ & $\begin{array}{c}\text { Complete } \\
\text { Bouguer } \\
\text { anomaly } \\
\text { (mGal) }\end{array}$ & $\begin{array}{c}\text { Isostatic } \\
\text { anomaly } \\
\text { (mGal) }\end{array}$ \\
\hline 07DLV001 & -114.9845 & 37.6418 & 5102.0 & 979478.63 & -2.36 & 0.79 & -177.00 & -9.57 \\
\hline 07DLV002 & -114.9872 & 37.6337 & 5041.0 & 979476.45 & -9.56 & 0.52 & -182.38 & -15.23 \\
\hline 07DLV003 & -114.9898 & 37.6257 & 5002.4 & 979477.81 & -11.13 & 0.61 & -182.54 & -15.69 \\
\hline 07DLV004 & -114.9938 & 37.6103 & 4955.2 & 979478.39 & -13.65 & 0.43 & -183.62 & -17.39 \\
\hline 07DLV005 & -114.9925 & 37.5853 & 4971.6 & 979472.67 & -15.64 & 0.53 & -186.08 & -20.83 \\
\hline 07DLV006 & -114.9922 & 37.5788 & 5002.2 & 979469.73 & -15.12 & 0.55 & -186.58 & -21.63 \\
\hline 07DLV007 & -114.9918 & 37.5733 & 5032.1 & 979465.53 & -16.04 & 0.58 & -188.50 & -23.77 \\
\hline 07DLV008 & -114.9908 & 37.5618 & 5090.3 & 979462.11 & -12.99 & 0.69 & -187.33 & -23.10 \\
\hline 07DLV009 & -114.9898 & 37.5493 & 5153.6 & 979458.29 & -9.76 & 0.81 & -186.15 & -22.44 \\
\hline 07DLV010 & -114.9912 & 37.5290 & 5272.8 & 979448.62 & -6.45 & & -186.63 & -23.83 \\
\hline 07DLV011 & -114.9948 & 37.5198 & 5352.1 & 979443.73 & & & & -23.28 \\
\hline 07DLV012 & -114.9963 & 37.5117 & 5375.3 & 979442.06 & -1.87 & 1.64 & -185.01 & -23.03 \\
\hline 07DLV013 & -114.9788 & 37.5653 & 5030.9 & 979465.01 & & 0.49 & -188.48 & -24.01 \\
\hline 07DLV014 & -114.9738 & 37.5547 & 5058.6 & 979461.11 & -16.34 & 51 & & -25.76 \\
\hline 07DLV015 & -114.9780 & 37.5495 & 5094.1 & 979458.79 & -14.87 & 61 & 9.42 & -25.65 \\
\hline 07DLV016 & -114.9607 & 37.5653 & 4974.7 & 979465.36 & -20.91 & 36 & -191.62 & -27.09 \\
\hline 07DLV018 & -114.9460 & 37.5770 & 4903.6 & 979470.82 & -23.15 & 0.30 & -191.48 & -26.33 \\
\hline 07DLV019 & -114.9383 & 37.5835 & 4878.4 & 979473.63 & -23.28 & 0.31 & -190.74 & -25.28 \\
\hline 07DLV020 & -114.9263 & 37.5878 & & 979473.87 & & 9 & & -24.85 \\
\hline 07DLV021 & -114.9403 & 37.5960 & 4895.5 & 979473.34 & -23.05 & 0.31 & & -25.17 \\
\hline 07DLV022 & -114.9450 & 37.6072 & & 979471 & & .30 & & -24.08 \\
\hline 07DLV023 & -114.9580 & 37.5590 & 4987.3 & 979463.39 & -21.14 & 0.37 & -192.27 & -27.97 \\
\hline 07DLV024 & -114.9475 & 37.5558 & 4964.9 & 979463.64 & -22.72 & 0.35 & -193.11 & -28.87 \\
\hline 07DLV025 & -114.9343 & 37.5518 & 4936.4 & 979464.09 & -24.60 & & & -29.89 \\
\hline 07DLV026 & -114.9240 & 37.5 & 07.5 & 9794 & -26.13 & 33 & -194.57 & -30.51 \\
\hline 07DLV027 & -114.9130 & 37.5455 & 4906.0 & 979466.09 & -24.90 & 0.35 & -193.27 & -29.26 \\
\hline 07DLV028 & -114.9050 & 37.5430 & 4874.5 & 979467.60 & -26.14 & 0.37 & -193.41 & -29.41 \\
\hline 07DLV029 & -114.8968 & 37.5405 & 4847.5 & 979468.43 & -27.63 & 0.37 & -193.97 & -30.01 \\
\hline 07DLV030 & -114.8885 & 37.5383 & 4819.2 & 979469.04 & -29.49 & 0.40 & -194.83 & -30.93 \\
\hline 07DLV031 & -114.8790 & 37.5352 & & 979471 & -27.40 & & 2.60 & -28.78 \\
\hline 07DLV032 & -114.8697 & 37.5323 & 4857.7 & 979466.64 & -27.74 & 0.47 & -194.34 & -30.59 \\
\hline 07DLV033 & -114.8572 & 37.5285 & 4930.4 & 979460.41 & -26.80 & 0.54 & -195.82 & -32.16 \\
\hline 07DLV034 & -114.7947 & 37.6197 & 4986.1 & 979475.31 & -14.64 & 0.62 & -185.48 & -17.65 \\
\hline 07DLV035 & -114.9800 & 37.6160 & 4958.6 & 979474.78 & -17.43 & 0.35 & -187.60 & -21.09 \\
\hline 07DLV036 & -114.9640 & 37.6150 & & 979472.16 & -19.23 & 0.35 & & -23.18 \\
\hline 07DLV037 & -114.9272 & 37.6123 & 5000.0 & 979471.56 & -16.44 & 0.3 & -188.06 & -21.45 \\
\hline 07DLV038 & -114.8873 & 37.6110 & 4916.2 & 979472.87 & -22.89 & 0.30 & -191.65 & -24.84 \\
\hline 07DLV039 & -114.8613 & 37.6133 & 4838.8 & 979475.58 & -27.66 & 0.34 & -193.74 & -26.65 \\
\hline 07DLV040 & -114.8305 & 37.6163 & 4881.3 & 979473.87 & -25.64 & 0.41 & -193.10 & -25.67 \\
\hline 07DLV041 & -114.8085 & 37.6185 & 4953.1 & 979472.81 & -20.14 & 0.51 & -189.96 & -22.28 \\
\hline 07DLV042 & -114.6945 & 37.9790 & 5090.1 & 979495.44 & -16.20 & 1.06 & -190.16 & -8.32 \\
\hline 07DLV043 & -114.6622 & 37.9800 & 5474.8 & 979473.69 & -1.88 & 1.50 & -188.56 & -6.34 \\
\hline 07DLV044 & -114.6672 & 37.9840 & 5423.3 & 979476.76 & -4.00 & 1.43 & -188.99 & -6.69 \\
\hline 07DLV045 & -114.6603 & 37.9852 & 5538.3 & 979469.14 & -0.92 & 1.58 & -189.69 & -7.25 \\
\hline 07DLV046 & -114.6530 & 37.9863 & 5668.3 & 979462.21 & 4.27 & 1.85 & -188.67 & -6.14 \\
\hline 07DLV047 & -114.6478 & 37.9865 & 5751.6 & 979455.46 & 5.33 & 1.89 & -190.42 & -7.83 \\
\hline
\end{tabular}




\begin{tabular}{|c|c|c|c|c|c|c|c|c|}
\hline 07DLV048 & -114.6417 & 37.9875 & 5864.3 & 979449.65 & 10.03 & 2.09 & -189.38 & -6.70 \\
\hline 07DLV049 & -114.6357 & 37.9875 & 5978.1 & 979444.14 & 15.21 & 2.33 & -187.84 & -5.12 \\
\hline 07DLV050 & -114.6298 & 37.9868 & 6090.9 & 979438.23 & 19.96 & 2.61 & -186.66 & -3.98 \\
\hline 07DLV051 & -114.6993 & 37.9782 & 5035.5 & 979497.03 & -19.67 & 0.96 & -191.86 & -10.09 \\
\hline 07DLV052 & -114.7122 & 37.9765 & 4906.8 & 979497.48 & -31.16 & 0.80 & -199.11 & -17.53 \\
\hline 7DLV053 & -114.7173 & 37.9767 & 4867.7 & 979497.14 & -35.20 & 0.74 & -201.87 & -20.35 \\
\hline 07DLV054 & -114.7225 & 37.9767 & 4834.9 & 979496.68 & -38.74 & 0.66 & -204.37 & -22.92 \\
\hline 07DLV055 & -114.7335 & 37.9775 & 4780.9 & 979496.61 & -43.96 & 0.57 & -207.83 & -26.48 \\
\hline 07DLV056 & -114.7400 & 37.9792 & 4773.4 & 979496.98 & -44.44 & 0.50 & -208.12 & -26.76 \\
\hline 07DLV057 & -114.7452 & 38.1020 & 5252.0 & 979497.42 & -9.80 & 0.56 & -189.80 & -4.43 \\
\hline J7DLV058 & -114.7273 & 38.0935 & 5264.3 & 979497.68 & -7.64 & 0.80 & -187.82 & -2.54 \\
\hline 07DLV059 & -114.7615 & 38.0757 & 5042.3 & 979495.85 & -28.77 & 0.37 & -201.79 & -17.48 \\
\hline 07DLV060 & -114.7777 & 38.0678 & 4981.8 & 979499.51 & -30.11 & 0.31 & -201.11 & -17.25 \\
\hline 07DLV061 & -114.8043 & 38.0552 & 4973.5 & 979501.14 & -28.15 & 0.24 & -198.94 & -15.77 \\
\hline 07DLV062 & -114.7847 & 38.0643 & 4969.6 & 979506.05 & -24.41 & 0.28 & -195.02 & -11.32 \\
\hline 07DLV063 & -114.8137 & 38.0495 & 4956.4 & 979510.08 & -20.32 & 0.27 & -190.49 & -7.64 \\
\hline 07DLV064 & -114.8250 & 38.0428 & 4997.5 & 979507.46 & -18.49 & 0.28 & -190.06 & -7.61 \\
\hline 07DLV065 & -114.8353 & 38.0405 & 5045.3 & 979506.64 & -14.61 & 0.29 & -187.81 & -5.49 \\
\hline 07DLV066 & -114.8558 & 38.0368 & 5158.7 & 979504.50 & -5.77 & 0.35 & -182.79 & -0.80 \\
\hline 07DLV067 & -114.8277 & 37.8550 & 4656.1 & 979518.76 & -22.80 & 0.29 & -182.68 & -6.65 \\
\hline 07DLV068 & -114.8128 & 37.8552 & 4613.8 & 979508.37 & -37.19 & 0.25 & -195.65 & -19.46 \\
\hline 07DLV069 & -114.8043 & 37.8552 & 4605.7 & 979501.19 & -45.13 & 0.24 & -203.32 & -27.06 \\
\hline 07DLV070 & -114.7933 & 37.8553 & 4608.6 & 979495.91 & -50.15 & 0.23 & -208.45 & -32.05 \\
\hline 07DLV071 & -114.7800 & 37.8555 & 4612.4 & 979494.73 & -50.99 & 0.24 & -209.41 & -32.90 \\
\hline 07DLV072 & -114.7733 & 37.8555 & 4612.6 & 979496.01 & -49.69 & 0.26 & -208.11 & -31.53 \\
\hline 07DLV073 & -114.7610 & 37.8698 & 4625.8 & 979498.90 & -46.81 & 0.31 & -205.63 & -28.41 \\
\hline 07DLV074 & -114.7498 & 37.8742 & 4629.6 & 979501.82 & -43.92 & 0.38 & -202.79 & -25.27 \\
\hline 07DLV075 & -114.7342 & 37.8793 & 4663.9 & 979509.26 & -33.70 & 0.51 & -193.63 & -15.76 \\
\hline 07DLV076 & -114.9800 & 37.3673 & 4724.1 & 979475.84 & -16.70 & 0.69 & -178.50 & -23.29 \\
\hline 07DLV077 & -114.9705 & 37.3572 & 4706.1 & 979476.16 & -17.18 & 0.66 & -178.40 & -23.71 \\
\hline 07DLV078 & -114.9358 & 37.3343 & 4540.4 & 979480.58 & -26.35 & 0.44 & -182.11 & -28.56 \\
\hline 07DLV079 & -114.9262 & 37.3333 & 4545.3 & 979477.94 & -28.44 & 0.45 & -184.36 & -30.82 \\
\hline 07DLV080 & -114.9253 & 37.3277 & 4548.1 & 979478.69 & -26.93 & 0.47 & -182.93 & -29.73 \\
\hline 07DLV081 & -114.9277 & 37.3227 & 4543.4 & 979480.15 & -25.48 & 0.48 & -181.30 & -28.43 \\
\hline 07DLV082 & -114.9327 & 37.3123 & 4533.9 & 979483.14 & -22.48 & 0.54 & -177.92 & -25.59 \\
\hline 07DLV083 & -114.9390 & 37.2995 & 4552.3 & 979484.44 & -18.33 & 0.62 & -174.32 & -22.73 \\
\hline 07DLV084 & -114.9572 & 37.2968 & 4543.2 & 979485.83 & -17.57 & 0.62 & -173.24 & -21.81 \\
\hline 07DLV085 & -114.9643 & 37.3013 & 4539.7 & 979485.50 & -18.62 & 0.62 & -174.18 & -22.50 \\
\hline 07DLV086 & -114.9655 & 37.3068 & 4537.5 & 979485.52 & -19.28 & 0.66 & -174.72 & -22.72 \\
\hline 07DLV087 & -114.9658 & 37.3117 & 4535.4 & 979485.77 & -19.65 & 0.99 & -174.69 & -22.42 \\
\hline 07DLV088 & -114.9678 & 37.3185 & 4540.0 & 979486.47 & -19.11 & 0.73 & -174.57 & -21.94 \\
\hline 07DLV089 & -114.9698 & 37.3372 & 4575.7 & 979484.27 & -19.59 & 0.64 & -176.36 & -22.70 \\
\hline 07DLV090 & -114.9707 & 37.3450 & 4622.7 & 979480.76 & -19.36 & 0.64 & -177.74 & -23.69 \\
\hline 07DLV091 & -114.9687 & 37.3747 & 4893.0 & 979465.38 & -11.92 & 1.00 & -179.19 & -23.64 \\
\hline 07DLV092 & -114.9692 & 37.3838 & 4851.5 & 979467.19 & -14.81 & 0.99 & -180.67 & -24.61 \\
\hline 07DLV093 & -114.9745 & 37.3923 & 4880.9 & 979465.53 & -14.45 & 0.88 & -181.43 & -24.95 \\
\hline 07DLV094 & -114.9643 & 37.3960 & 4824.4 & 979468.35 & -17.26 & 0.77 & -182.42 & -25.71 \\
\hline 07DLV095 & -114.9577 & 37.4035 & 4800.7 & 979471.83 & -16.66 & 0.68 & -181.09 & -23.96 \\
\hline 07DLV096 & -114.9503 & 37.4087 & 4743.4 & 979476.60 & -17.73 & 0.63 & -180.26 & -22.82 \\
\hline 07DLV097 & -114.9432 & 37.4138 & 4703.5 & 979479.40 & -19.13 & 0.59 & -180.33 & -22.59 \\
\hline 07DLV098 & -114.9312 & 37.4235 & 4665.3 & 979476.92 & -26.05 & 0.54 & -185.98 & -27.71 \\
\hline 07DLV099 & -114.9232 & 37.4303 & 4631.6 & 979476.37 & -30.36 & 0.51 & -189.17 & -30.46 \\
\hline 07DLV100 & -114.9103 & 37.4328 & 4622.7 & 979472.29 & -35.49 & 0.47 & -194.05 & -35.15 \\
\hline 07DLV101 & -114.8988 & 37.4367 & 4633.8 & 979468.48 & -38.60 & 0.46 & -197.53 & -38.35 \\
\hline DLV102 & -114.8883 & 37.4410 & 4645.2 & 979466.67 & -39.71 & 0.48 & -199.03 & -39.60 \\
\hline 7DLV103 & -114.8790 & 37.4393 & 4661.1 & 979464.96 & -39.78 & 0.51 & -199.60 & -40.21 \\
\hline
\end{tabular}


Table 1. Principal facts for new gravity stations, Dry Lake \& Delamar Valleys, Nevada

\begin{tabular}{|c|c|c|c|c|c|c|c|c|}
\hline 07DLV104 & -114.8802 & 37.4213 & 4620.5 & 979463.71 & -43.28 & 0.51 & -201.72 & -43.29 \\
\hline 07DLV105 & -114.8870 & 37.4073 & 4596.4 & 979464.12 & -43.91 & 0.49 & -201.54 & -43.83 \\
\hline 07DLV106 & -114.8947 & 37.4002 & 4582.5 & 979465.83 & -42.88 & 0.47 & -200.06 & -42.74 \\
\hline 07DLV107 & -114.9317 & 37.4038 & 4643.5 & 979477.48 & -25.82 & 0.54 & -185.01 & -27.71 \\
\hline 07DLV108 & -114.9445 & 37.4012 & 4694.6 & 979481.18 & -17.08 & 0.57 & -177.99 & -20.87 \\
\hline 07DLV109 & -114.9537 & 37.3972 & 4743.0 & 979475.89 & -17.47 & 0.62 & -180.00 & -23.14 \\
\hline 07DLV110 & -114.9182 & 37.3922 & 4568.9 & 979473.32 & -35.97 & 0.45 & -192.70 & -35.94 \\
\hline 07DLV111 & -114.8933 & 37.3938 & 4576.5 & 979465.17 & -43.55 & 0.47 & -200.52 & -43.53 \\
\hline 07DLV112 & -114.8997 & 37.3813 & 4561.4 & 979466.88 & -42.17 & 0.46 & -198.64 & -42.39 \\
\hline 07DLV113 & -114.8758 & 37.4147 & 4619.2 & 979463.20 & -43.33 & 0.53 & -201.70 & -43.56 \\
\hline 07DLV114 & -114.9055 & 37.3690 & 4553.5 & 979469.33 & -39.39 & 0.45 & -195.59 & -40.05 \\
\hline 07DLV115 & -114.9128 & 37.3532 & 4546.9 & 979473.76 & -34.20 & 0.44 & -190.18 & -35.52 \\
\hline 07DLV116 & -114.9193 & 37.3398 & 4549.6 & 979476.46 & -30.08 & 0.45 & -186.15 & -32.24 \\
\hline 07DLV117 & -114.9388 & 37.3168 & 4540.5 & 979481.58 & -23.81 & 0.49 & -179.53 & -26.99 \\
\hline 07DLV118 & -114.9438 & 37.3123 & 4540.4 & 979483.00 & -22.01 & 0.50 & -177.71 & -25.42 \\
\hline 07DLV119 & -114.9438 & 37.3063 & 4535.1 & 979483.90 & -21.08 & 0.52 & -176.58 & -24.63 \\
\hline 07DLV120 & -114.9607 & 37.3268 & 4537.5 & 979485.61 & -20.94 & 0.44 & -176.60 & -23.50 \\
\hline 07DLV121 & -114.9563 & 37.3345 & 4541.7 & 979484.44 & -22.38 & 0.42 & -178.20 & -24.67 \\
\hline 07DLV122 & -114.9475 & 37.3303 & 4542.2 & 979484.09 & -22.32 & 0.44 & -178.14 & -24.84 \\
\hline 07DLV123 & -114.9387 & 37.3303 & 4537.2 & 979481.87 & -25.01 & 0.44 & -180.66 & -27.33 \\
\hline 07DLV124 & -114.9427 & 37.3250 & 4542.0 & 979482.10 & -23.86 & 0.45 & -179.67 & -26.65 \\
\hline 07DLV125 & -114.9382 & 37.3210 & 4537.7 & 979480.91 & -25.11 & 0.46 & -180.75 & -27.98 \\
\hline 07DLV126 & -114.9162 & 37.3320 & 4572.1 & 979478.38 & -25.36 & 0.49 & -182.16 & -28.70 \\
\hline 07DLV127 & -114.9065 & 37.3308 & 4598.7 & 979478.44 & -22.70 & 0.55 & -180.35 & -26.95 \\
\hline 07DLV128 & -114.8973 & 37.3297 & 4622.6 & 979477.41 & -21.38 & 0.58 & -179.82 & -26.48 \\
\hline 07DLV129 & -114.8885 & 37.3285 & 4656.7 & 979475.52 & -19.97 & 0.63 & -179.52 & -26.22 \\
\hline 07DLV130 & -114.8777 & 37.3225 & 4691.2 & 979474.08 & -17.64 & 0.74 & -178.26 & -25.33 \\
\hline 07DLV131 & -114.8722 & 37.3265 & 4723.6 & 979471.20 & -17.82 & 0.74 & -179.56 & -26.36 \\
\hline 07DLV132 & -114.8682 & 37.3315 & 4730.4 & 979469.34 & -19.48 & 0.73 & -181.45 & -27.94 \\
\hline 07DLV133 & -114.8687 & 37.3402 & 4701.7 & 979469.57 & -22.70 & 0.69 & -183.74 & -29.71 \\
\hline 07DLV134 & -114.8687 & 37.3517 & 4672.3 & 979469.13 & -26.91 & 0.66 & -186.97 & -32.28 \\
\hline 07DLV135 & -114.8620 & 37.3270 & 4763.6 & 979469.14 & -16.17 & 0.84 & -179.17 & -25.93 \\
\hline 07DLV136 & -114.8507 & 37.3248 & 4821.6 & 979470.42 & -9.25 & 1.05 & -174.02 & -20.89 \\
\hline 07DLV137 & -114.8448 & 37.3218 & 4837.6 & 979467.73 & -10.16 & 1.39 & -175.15 & -22.22 \\
\hline 07DLV138 & -114.8532 & 37.3310 & 4785.6 & 979468.38 & -15.21 & 0.91 & -178.90 & -25.40 \\
\hline 07DLV139 & -114.8452 & 37.3392 & 4819.5 & 979466.48 & -14.62 & 1.00 & -179.38 & -25.37 \\
\hline 07DLV140 & -114.8247 & 37.3512 & 5073.2 & 979455.21 & -3.10 & 1.30 & -176.24 & -21.54 \\
\hline 07DLV141 & -114.8037 & 37.3558 & 5303.6 & 979442.60 & 5.54 & 1.62 & -175.16 & -20.19 \\
\hline 07DLV142 & -114.7952 & 37.3488 & 5472.6 & 979431.80 & 11.23 & 2.09 & -174.78 & -20.22 \\
\hline 07DLV143 & -114.7820 & 37.3482 & 5606.0 & 979424.60 & 16.63 & 2.21 & -173.82 & -19.32 \\
\hline 07DLV144 & -114.7817 & 37.3610 & 5466.1 & 979431.58 & 9.34 & 2.05 & -176.49 & -21.18 \\
\hline 07DLV145 & -114.8340 & 37.3515 & 4956.8 & 979459.36 & -9.92 & 1.11 & -179.27 & -24.55 \\
\hline 07DLV146 & -114.8357 & 37.3613 & 4928.8 & 979458.87 & -13.90 & 1.01 & -182.39 & -27.10 \\
\hline 07DLV147 & -114.8365 & 37.3672 & 4899.4 & 979458.34 & -17.71 & 0.96 & -185.24 & -29.63 \\
\hline 07DLV148 & -114.8370 & 37.3727 & 4882.9 & 979459.33 & -18.75 & 0.94 & -185.74 & -29.83 \\
\hline 07DLV149 & -114.8467 & 37.3792 & 4777.9 & 979462.93 & -25.58 & 0.79 & -189.12 & -32.84 \\
\hline 07DLV150 & -114.8548 & 37.3825 & 4712.8 & 979464.25 & -30.67 & 0.72 & -192.05 & -35.59 \\
\hline 07DLV151 & -114.8562 & 37.3765 & 4727.7 & 979464.20 & -28.80 & 0.73 & -190.68 & -34.54 \\
\hline 07DLV152 & -114.8342 & 37.3863 & 4838.2 & 979461.03 & -22.44 & 0.89 & -187.94 & -31.19 \\
\hline 07DLV153 & -114.8265 & 37.4080 & 4836.9 & 979465.79 & -19.69 & 0.97 & -185.08 & -27.11 \\
\hline 07DLV154 & -114.7147 & 37.8887 & 4805.4 & 979510.69 & -19.79 & 0.72 & -184.35 & -5.95 \\
\hline 07DLV155 & -114.7118 & 37.8885 & 4829.5 & 979510.34 & -17.86 & 0.75 & -183.22 & -4.78 \\
\hline 07DLV156 & -114.6760 & 37.8763 & 5243.7 & 979490.82 & 2.62 & 1.17 & -176.48 & 1.84 \\
\hline 07DLV157 & -114.6800 & 37.8783 & 5195.5 & 979493.10 & 0.19 & 1.16 & -177.27 & 1.06 \\
\hline 07DLV158 & -114.6818 & 37.8793 & 5174.9 & 979493.59 & -1.34 & 1.15 & -178.11 & 0.25 \\
\hline 07DLV159 & -114.6840 & 37.8802 & 5148.6 & 979494.04 & -3.44 & 1.11 & -179.35 & -0.97 \\
\hline
\end{tabular}


Table 1. Principal facts for new gravity stations, Dry Lake \& Delamar Valleys, Nevada.

$\begin{array}{lllllllll}\text { 07DLV160 } & -114.6860 & 37.8808 & 5122.2 & 979494.75 & -5.27 & 1.08 & -180.31 & -1.92 \\ \text { 07DLV161 } & -114.6882 & 37.8815 & 5093.2 & 979495.57 & -7.23 & 1.05 & -181.30 & -2.89 \\ \text { 07DLV162 } & -114.6905 & 37.8822 & 5071.1 & 979496.36 & -8.58 & 1.02 & -181.93 & -3.53 \\ \text { 07DLV163 } & -114.6927 & 37.8828 & 5045.7 & 979497.70 & -9.68 & 0.99 & -182.19 & -3.77 \\ \text { 07DLV164 } & -114.6950 & 37.8833 & 5021.7 & 979498.78 & -10.90 & 0.95 & -182.63 & -4.21 \\ \text { 07DLV165 } & -114.6973 & 37.8838 & 4996.4 & 979499.78 & -12.32 & 0.91 & -183.23 & -4.82 \\ \text { 07DLV166 } & -114.6992 & 37.8842 & 4972.7 & 979501.19 & -13.17 & 0.88 & -183.30 & -4.89 \\ \text { 07DLV167 } & -114.7013 & 37.8848 & 4949.5 & 979503.37 & -13.23 & 0.85 & -182.59 & -4.18 \\ \text { 07DLV168 } & -114.7033 & 37.8857 & 4925.8 & 979505.23 & -13.67 & 0.82 & -182.25 & -3.82 \\ \text { 07DLV169 } & -114.7055 & 37.8863 & 4901.9 & 979506.67 & -14.54 & 0.80 & -182.31 & -3.86 \\ \text { 07DLV170 } & -114.7077 & 37.8872 & 4878.5 & 979508.14 & -15.34 & 0.78 & -182.33 & -3.89 \\ \text { 07DLV171 } & -114.7098 & 37.8878 & 4856.7 & 979509.64 & -15.95 & 0.76 & -182.21 & -3.76 \\ \text { 07DLV172 } & -114.7448 & 37.8040 & 4656.3 & 979503.72 & -33.36 & 0.31 & -193.22 & -18.19 \\ \text { 07DLV173 } & -114.7577 & 37.8052 & 4605.3 & 979498.97 & -43.00 & 0.28 & -201.15 & -26.18 \\ \text { 07DLV174 } & -114.7322 & 37.6605 & 5083.0 & 979487.84 & 3.43 & 0.92 & -170.42 & -0.56 \\ \text { 07DLV175 } & -114.7347 & 37.6600 & 5064.1 & 979488.77 & 2.63 & 0.96 & -170.54 & -0.73 \\ \text { 07DLV176 } & -114.7368 & 37.6603 & 5050.5 & 979489.65 & 2.20 & 0.94 & -170.52 & -0.69 \\ \text { 07DLV177 } & -114.7390 & 37.6612 & 5036.7 & 979490.34 & 1.52 & 0.89 & -170.78 & -0.94 \\ \text { 07DLV178 } & -114.7413 & 37.6617 & 5011.9 & 979491.70 & 0.51 & 0.86 & -170.98 & -1.14 \\ \text { 07DLV179 } & -114.7433 & 37.6620 & 4989.6 & 979492.51 & -0.81 & 0.83 & -171.56 & -1.71 \\ \text { 07DLV180 } & -114.7457 & 37.6622 & 4963.5 & 979493.87 & -1.92 & 0.79 & -171.82 & -1.96 \\ \text { 07DLV181 } & -114.7478 & 37.6628 & 4931.8 & 979494.18 & -4.65 & 0.75 & -173.50 & -3.64 \\ \text { 07DLV182 } & -114.7498 & 37.6637 & 4909.4 & 979493.84 & -7.16 & 0.69 & -175.31 & -5.44 \\ \text { 07DLV183 } & -114.7523 & 37.6643 & 4887.4 & 979493.29 & -9.84 & 0.65 & -177.27 & -7.39 \\ \text { 07DLV184 } & -114.7545 & 37.6647 & 4863.6 & 979493.06 & -12.34 & 0.62 & -178.98 & -9.09 \\ \text { 07DLV185 } & -114.7577 & 37.6647 & 4840.7 & 979493.13 & -14.42 & 0.60 & -180.30 & -10.45\end{array}$


Table 2. Cenozoic density-depth function for the Cave to Delamar Valleys study area, eastcentral Nevada.

\begin{tabular}{|c|c|c|}
\hline $\begin{array}{c}\text { Depth range, } \\
\text { in kilometers }\end{array}$ & $\begin{array}{c}\text { Sedimentary rocks, } \\
\text { in } \mathbf{~ k g} / \mathbf{m}^{\mathbf{3}}\end{array}$ & $\begin{array}{c}\text { Volcanic rocks, } \\
\text { in } \mathbf{~ k g} / \mathbf{m}^{\mathbf{3}}\end{array}$ \\
\hline 0 to 0.2 & 2,020 & 2,220 \\
\hline 0.2 to 0.6 & 2,120 & 2,270 \\
\hline 0.6 to 1.2 & 2,320 & 2,320 \\
\hline$>1.2$ & 2,420 & 2,420 \\
\hline
\end{tabular}



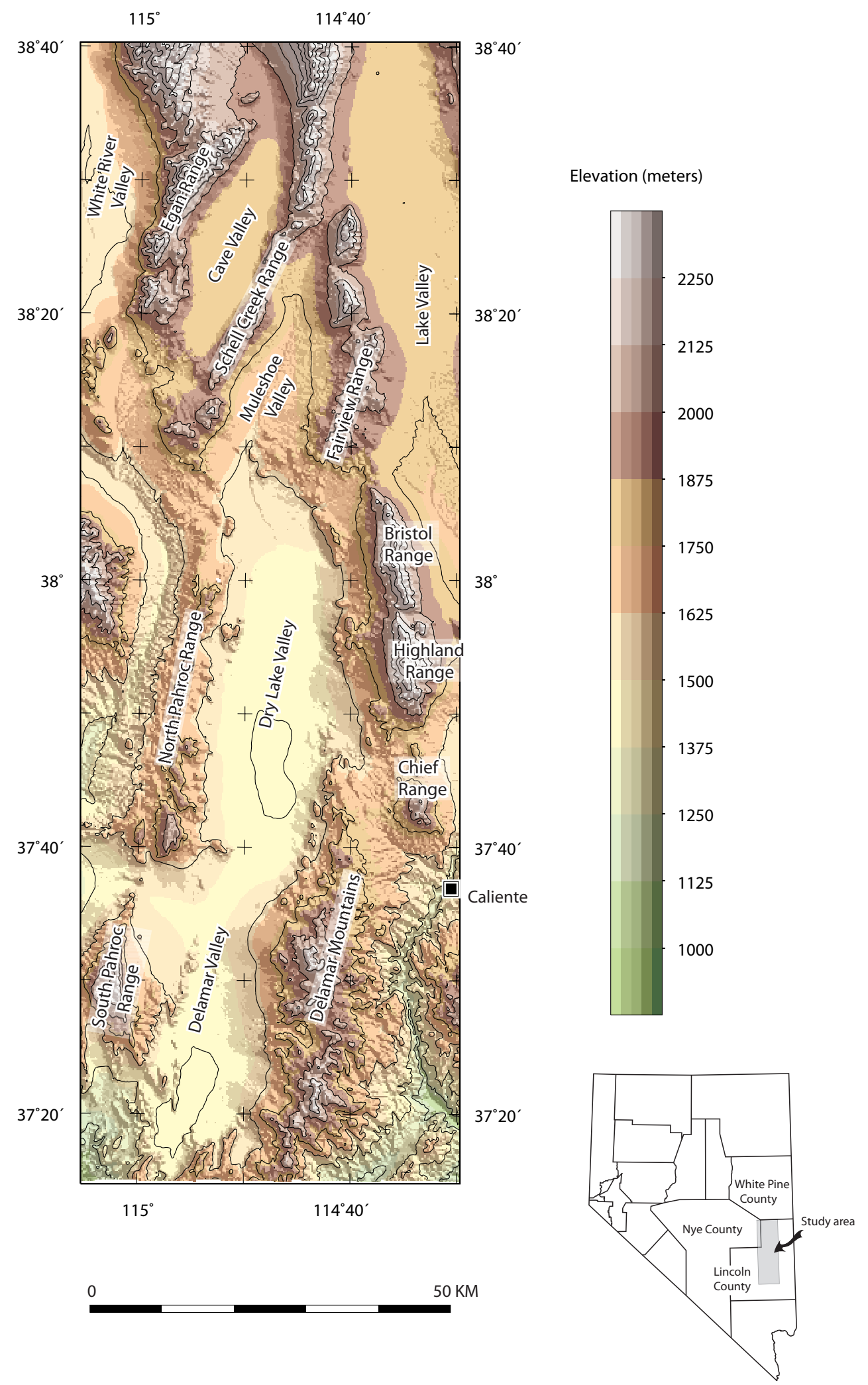

Figure 1. Shaded-relief map of the study area, east-central Nevada. Topographic contour interval is $200 \mathrm{~m}$. 


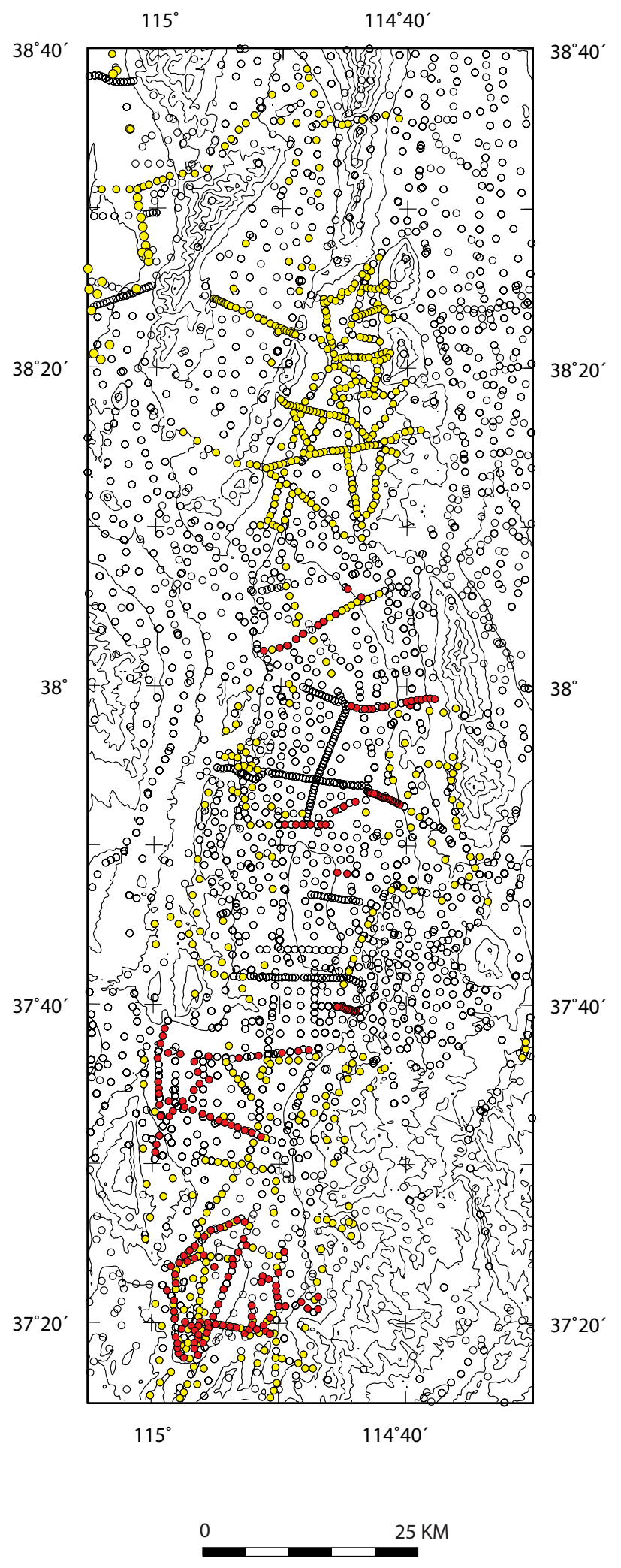

Figure 2. Locations of gravity stations in the study area. Open circles, previously available stations; Colored dots, stations added during the USGS-SNWA cooperative studies. $\bigcirc=$ Scheirer (2005) and Mankinen \& others (2007). $\bigcirc=$ This study. 


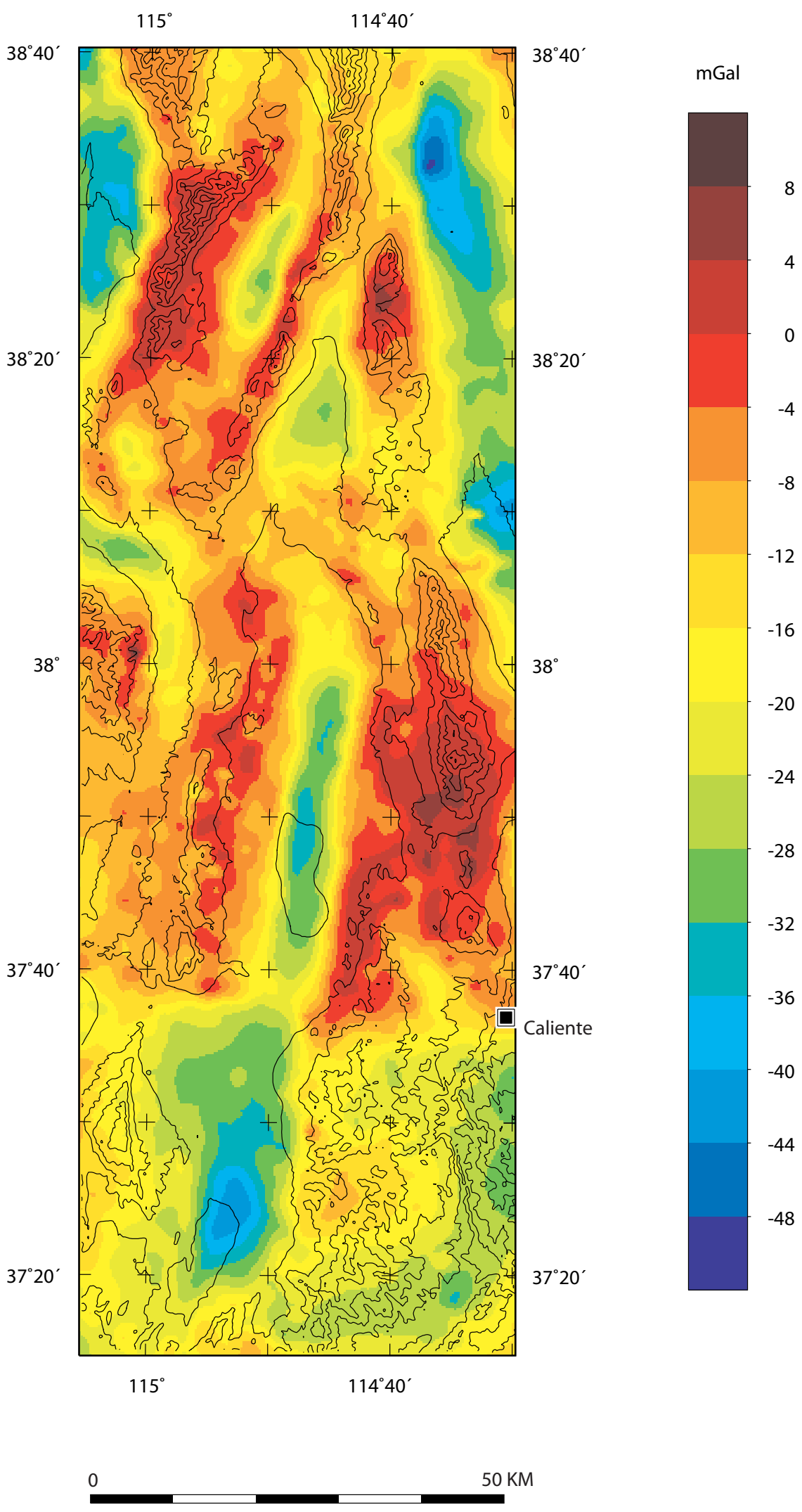

Figure 3. Isostatic gravity field of the study area. Anomalies reflect local density variations in the middle and upper crust. 


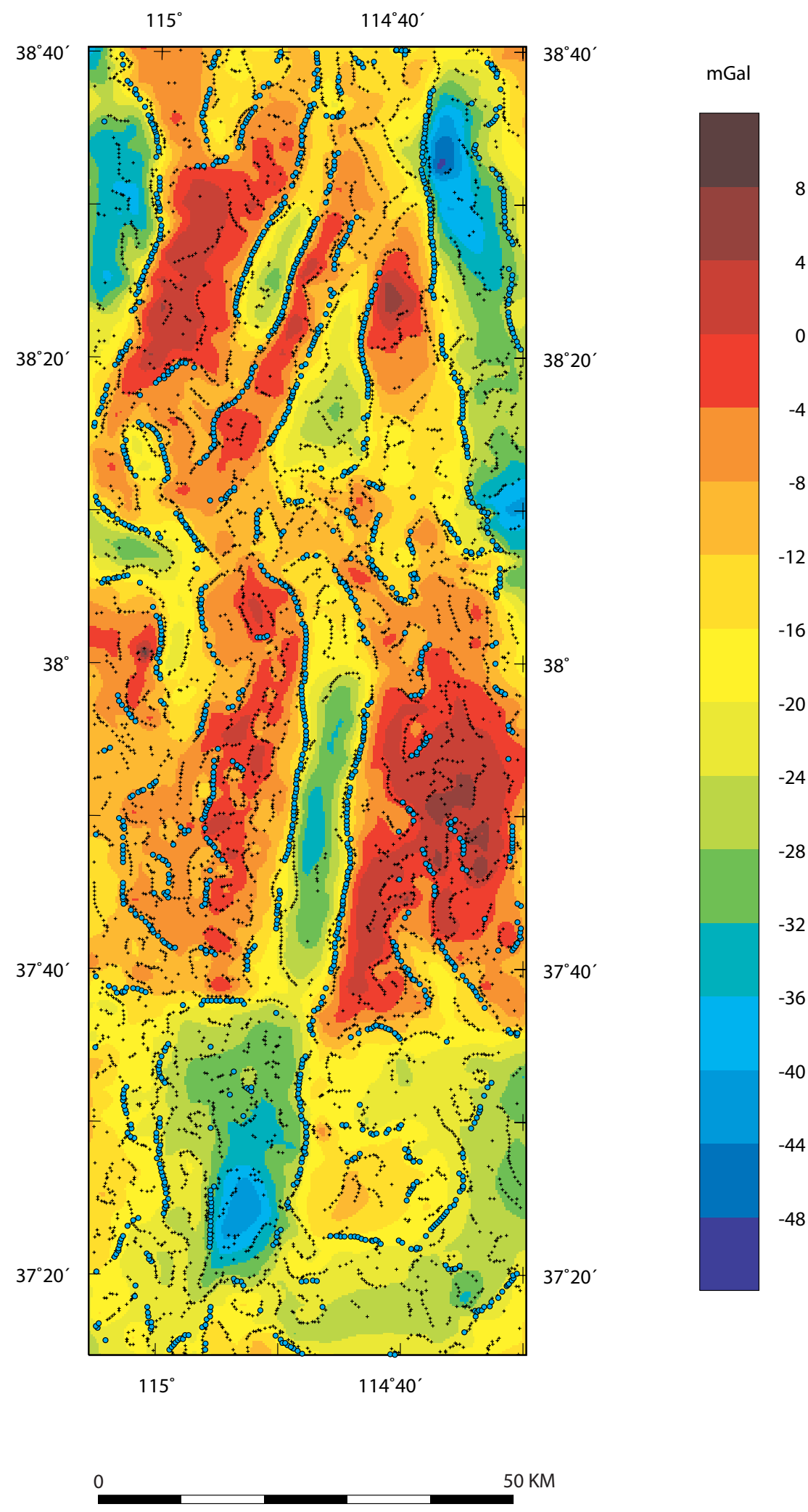

Figure 4. Isostatic gravity field showing maximum values of horizontal gradients (small crosses) calculated for the gravity anomalies. Colored dots are maxima of the horizontal gradients after analytically upward-continuing the observed anomalies by $2 \mathrm{~km}$ (see text). 


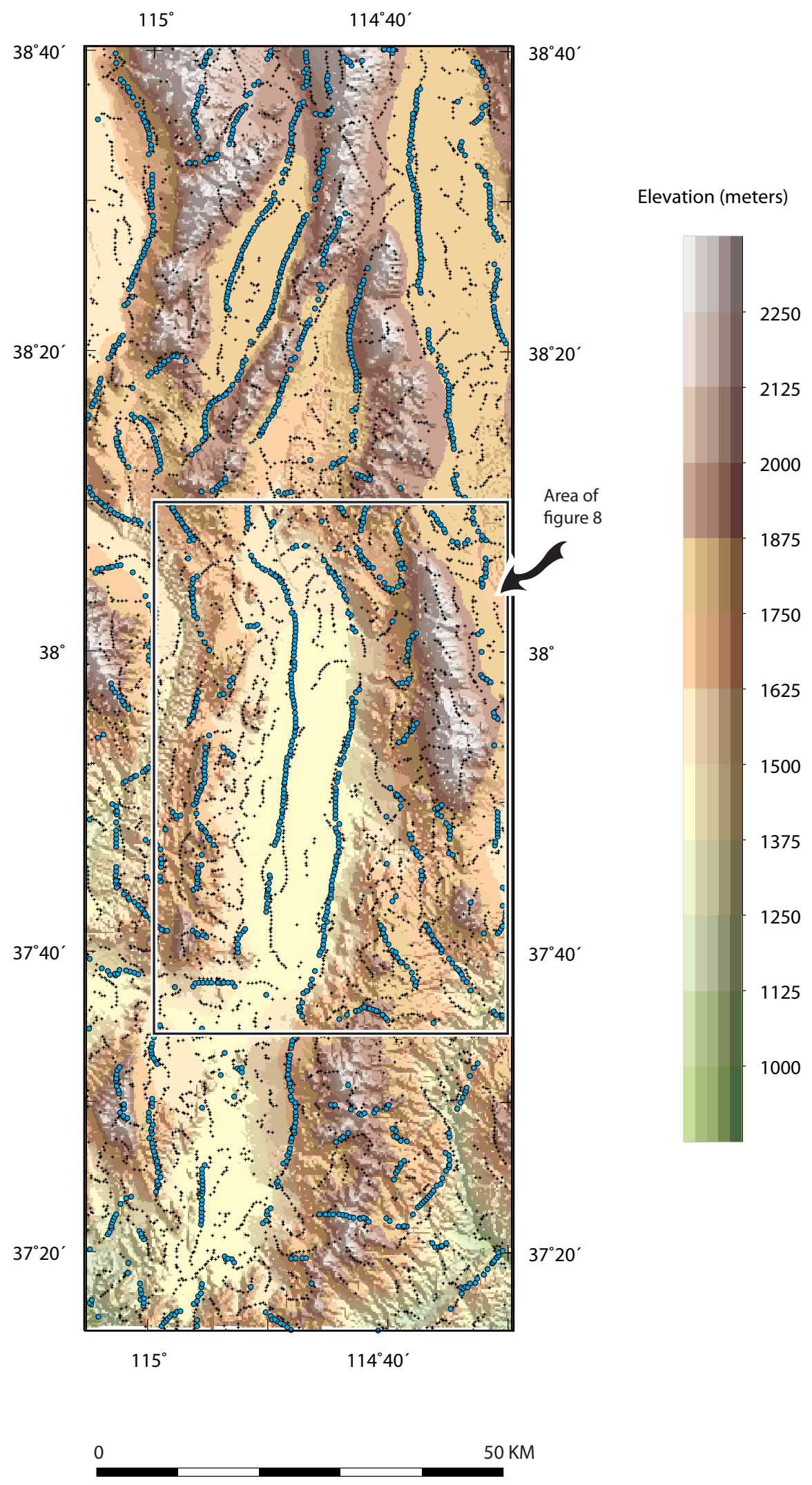

Figure 5. Maxima of the horizontal gradients of the gravity field superimposed on the shaded relief map of the study area. See figure 4 for further explanation. 


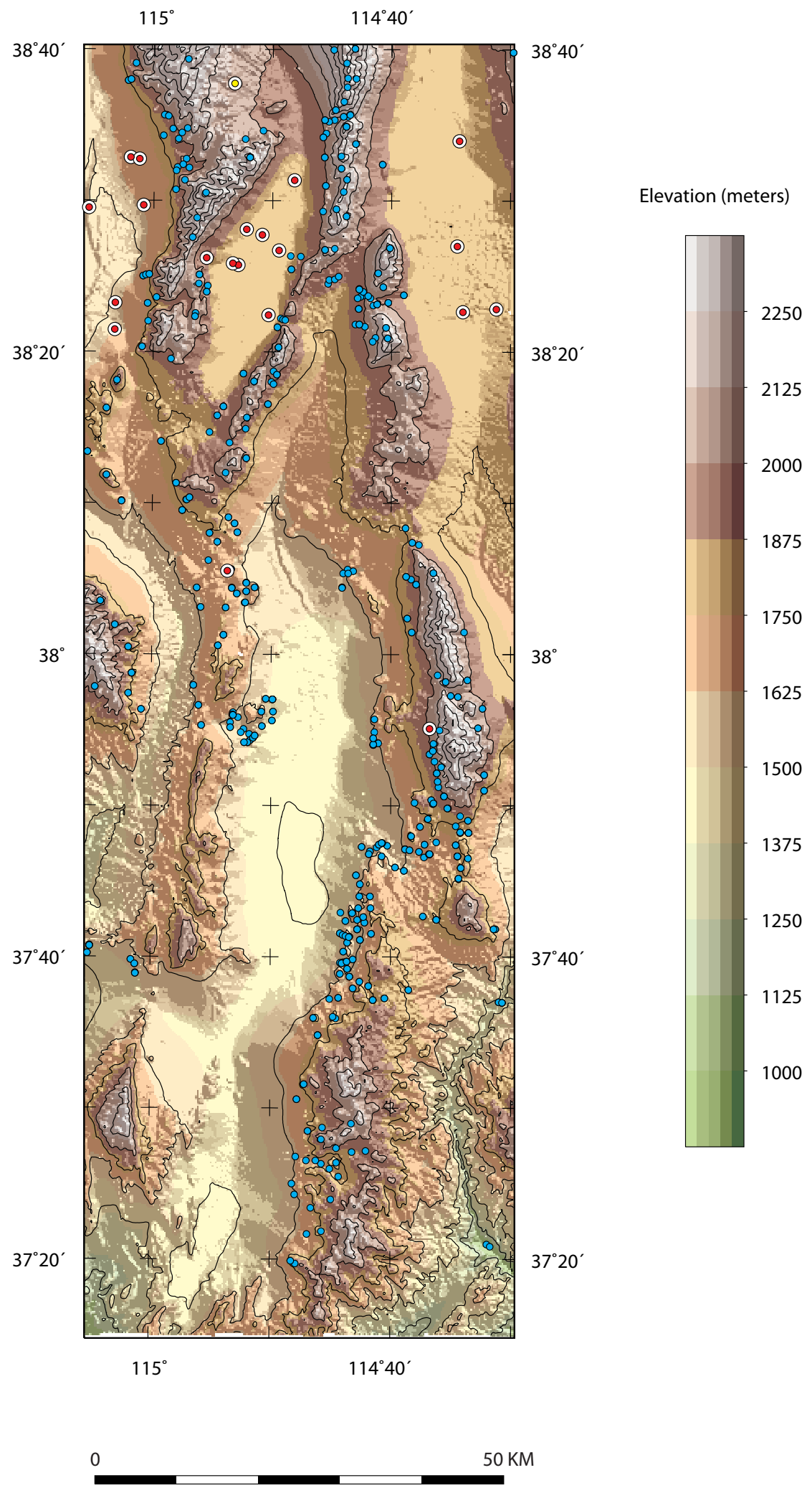

Figure 6. Constraints used for the gravity inversion. Blue dots, gravity stations located on preCenozoic basement; red/white dots, wells encountering pre-Cenozoic basement; yellow/white dot, minimum-depth constraint. 


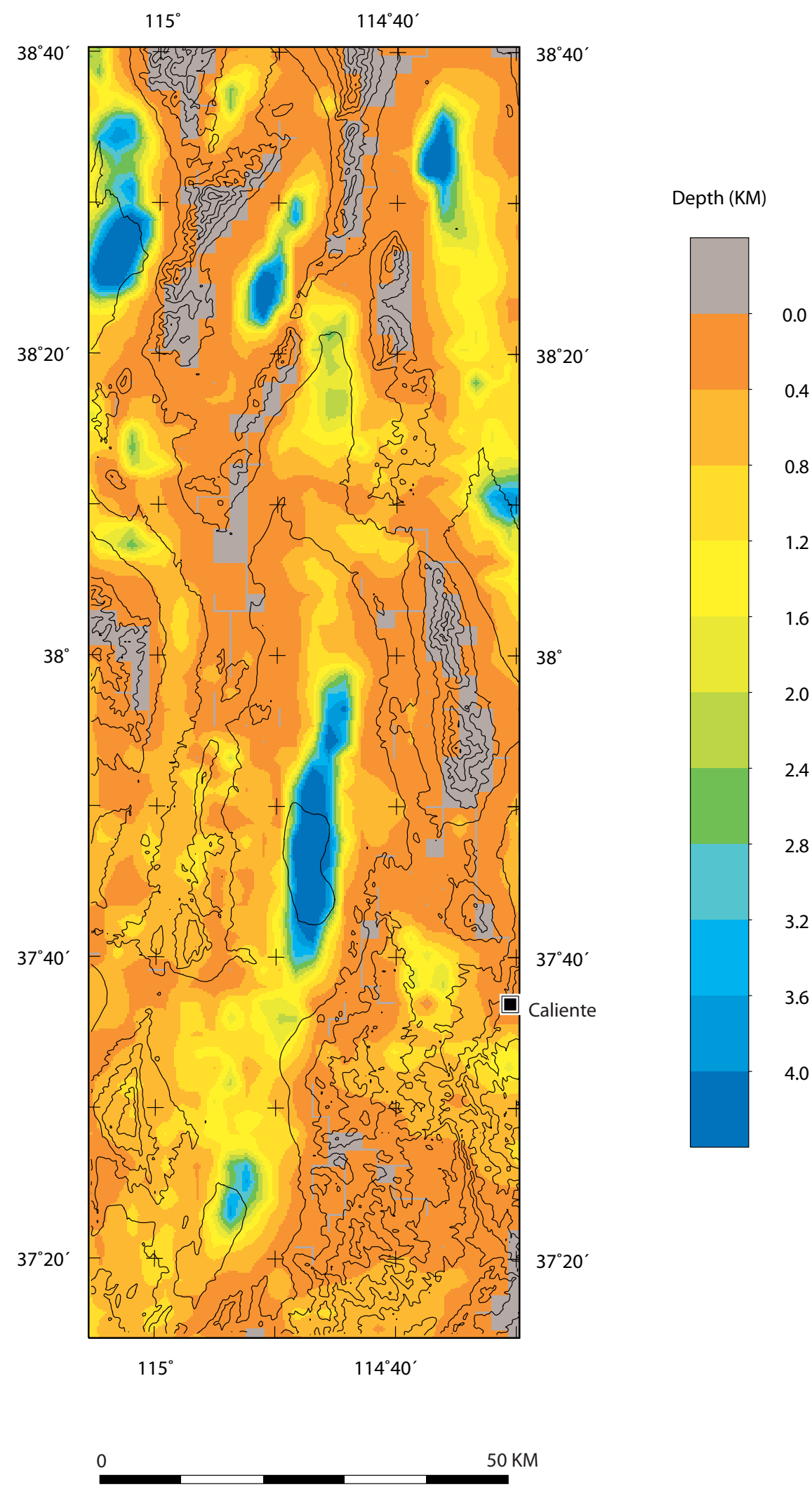

Figure 7. Depth to pre-Cenozoic basement calculated using the gravity inversion method of Jachens and Moring (1990). Gravity observations are from stations shown in figure 2. 


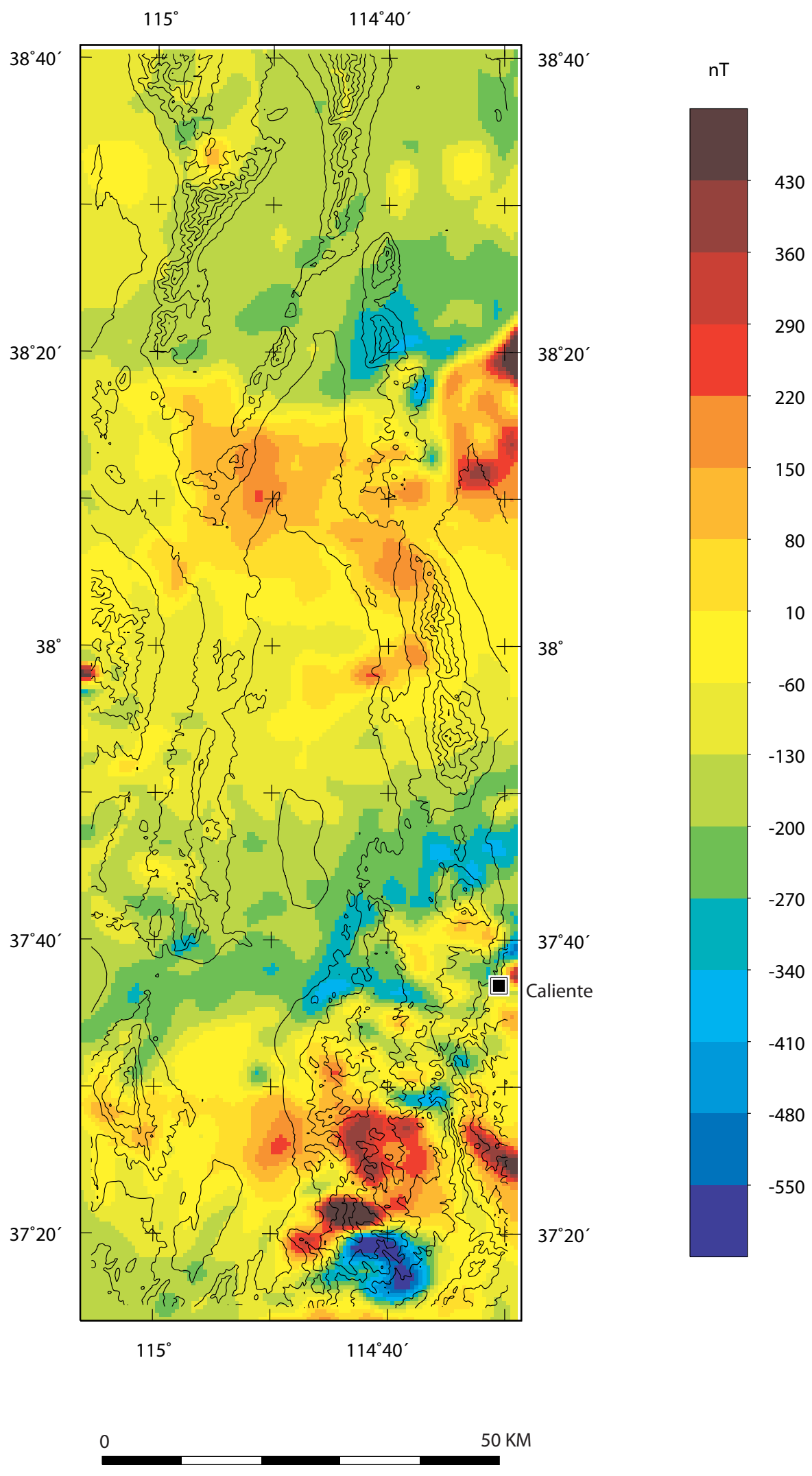

Figure 8. Aeromagnetic map of the study area. Colors represent measured magnetic field intensities relative to the International Geomagnetic Reference Field. 


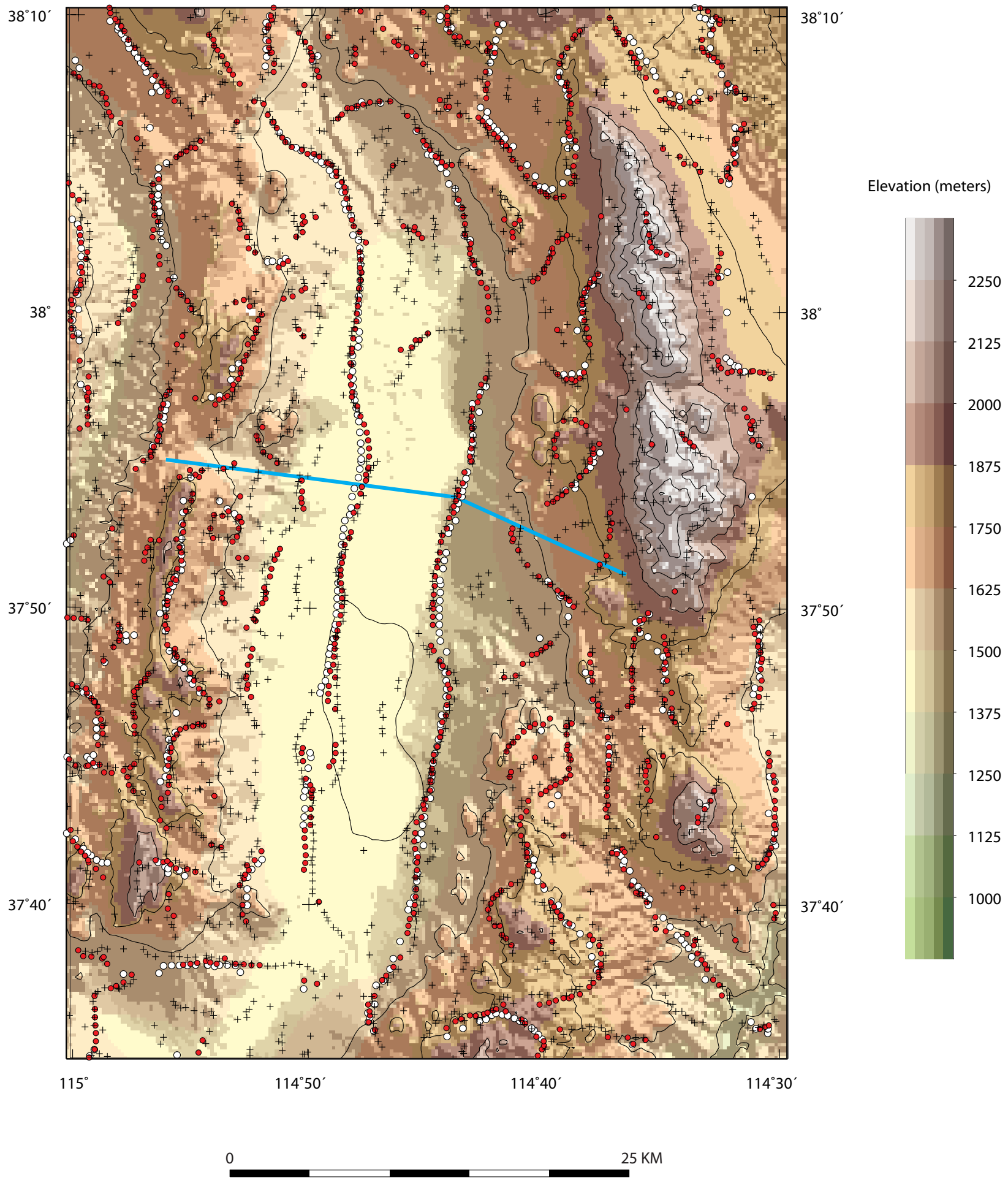

Figure 9. Transect (blue line) across Dry Lake Valley. Small crosses, maxima in the horizontal gradient of the gravity field; red dots, maxima in the 1-km upward-continued data; white dots, maxima in the 2-km upward-continued data (see text). 

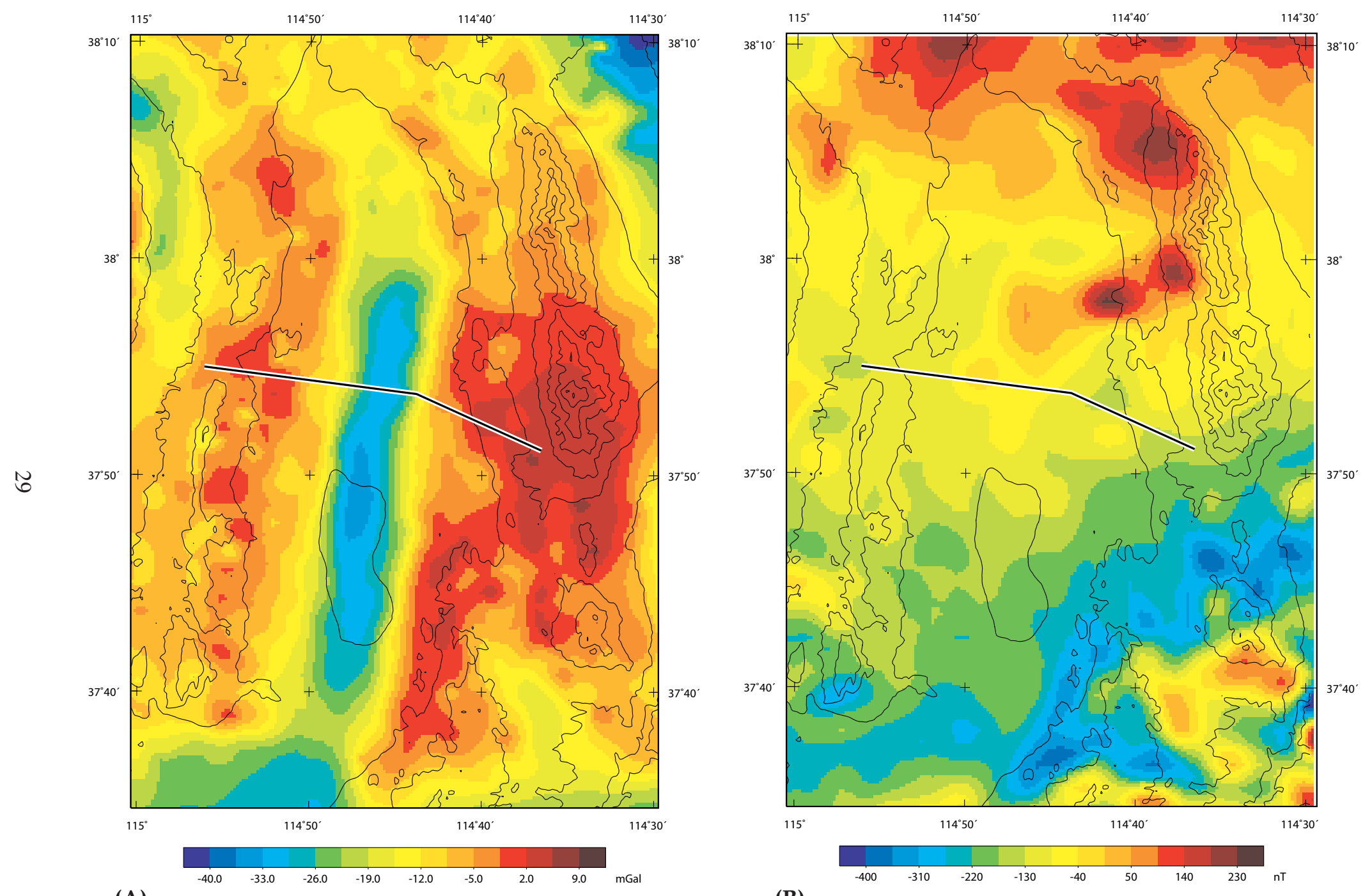

(A)

(B)

Figure 10. Portion of A, gravity and B, aeromagnetic grids showing location of transect (solid line) across Dry Lake Valley. 
DRY LAKE VALLEY CROSS-SECTION
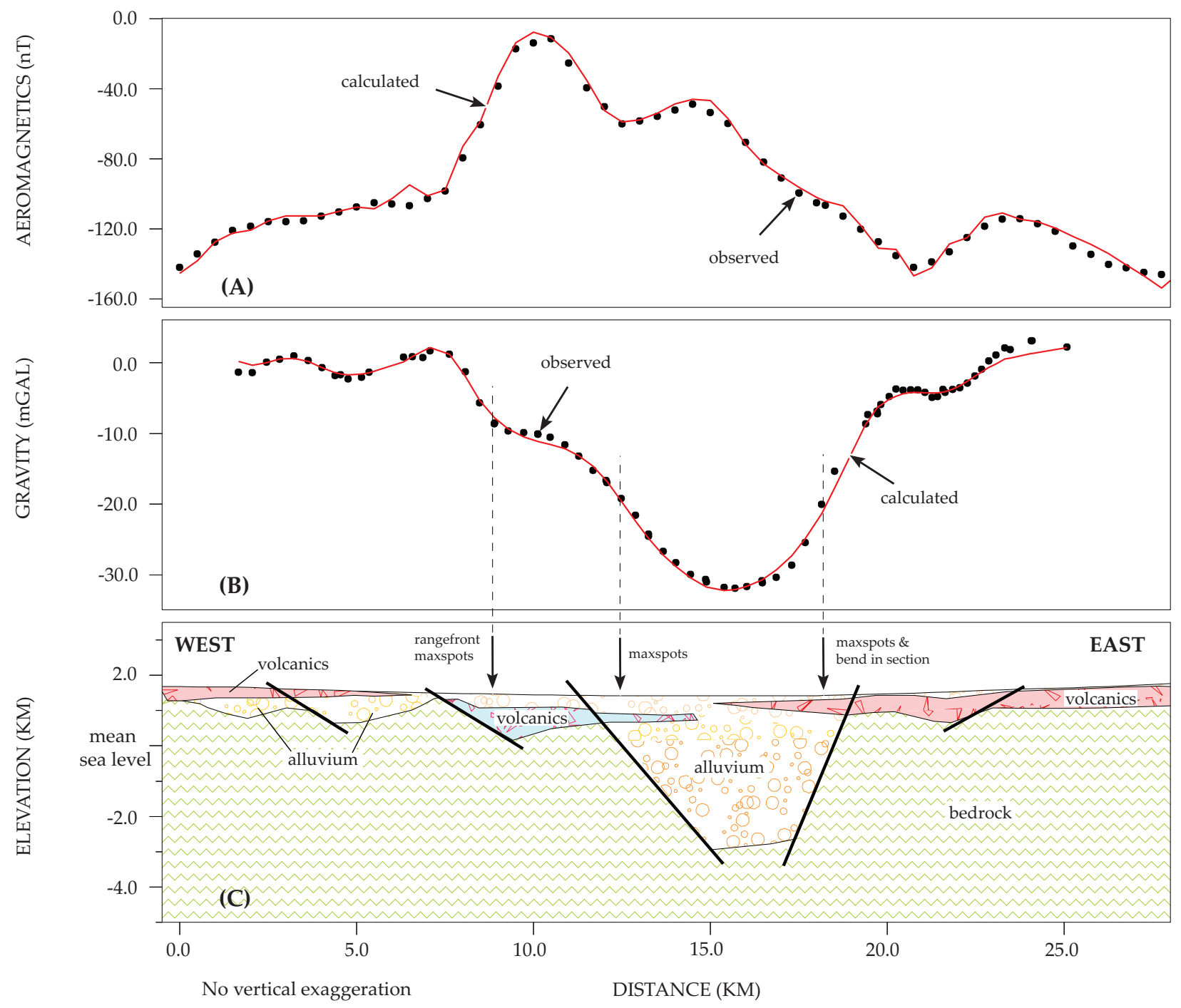

Figure 11. Geophysical forward model showing fits between observed and calculated magnetic (A) and gravity (B) profiles, and a geologic interpretation (C) of inferred subsurface structure. Heavy black lines indicate inferred faults. See text for physical properties of modeled bodies. 